PontIFícIa UniVERSIDADE CATÓLICA dO RIO DE JANEIRO

\title{
As estratégias aplicadas pelo Borussia Dortmund e os estádios brasileiros: Como alavancar a média de público?
}

Nome do Autor Antonio Manoel do NASCIMENTO

Trabalho de Conclusão de Curso

Centro de CIÊnCIAS SOCIAIS - CCS

DePARTAMENTO dE ADMINISTRAÇÃO

Graduação em Administração de Empresas 


\section{As estratégias aplicadas pelo Borussia Dortmund e os estádios brasileiros: Como alavancar a média de público?}

Trabalho de Conclusão de Curso

Trabalho de Conclusão de Curso, apresentado ao programa de graduação em Administração da PUC-Rio como requisito parcial para a obtenção do titulo de graduação em Administração.

Orientador(a): João Paulo Tinoco

Rio de Janeiro, 10 de junho de 2015. 
"Não importa o que aconteça, tudo vai ficar melhor." 


\section{Resumo}

Do Nascimento, Antonio Manoel. Tinoco, João Paulo. As estratégias aplicadas pelo Borussia Dortmund e os estádios brasileiros: Como alavancar a média de público. Rio de Janeiro, 2015. p.56 Trabalho de Conclusão de Curso - Departamento de Administração. Pontifícia Universidade Católica do Rio de Janeiro.

O presente trabalho tem como principal objetivo avaliar como as estratégias utilizadas pelo Borussia Dortmund, clube de futebol alemão, podem ser aplicadas aos clubes brasileiros de futebol. Através de estudos de casos do clube aurinegro e pesquisas com consumidores (torcedores) e um gestor de clube brasileiro, foi possível avaliar o cenário atual dos clubes brasileiros no que diz respeito ao planejamento estratégico e sugerir como as ações feitas pelo Borussia podem melhorar a atratividade de seus estádios.

Palavras- chave

Planejamento estratégico, marketing esportivo, futebol brasileiro, clubes brasileiros de futebol, estádios de futebol, estudo de caso, Borussia Dortmund, Flamengo, Vasco, Fluminense, Botafogo.

\section{Abstract}

Do Nascimento, Antonio Manoel. Tinoco, João Paulo. Strategies applied by Borussia Dortmund and the brazilian stadiums: How to increase the average attendance. Rio de Janeiro, 2015. p.56 Trabalho de Conclusão de Curso - Departamento de Administração. Pontifícia Universidade Católica do Rio de Janeiro.

The main objective of this project is to analyze how the strategies used by Borussia Dortmund, german soccer team, could be applied to the brazilian soccer teams. Through a case study and researches with consumers (fans) and a brazilian soccer team manager, it was possible to evaluate the current scenario of the brazilian soccer teams regarding the strategic planning and suggest how Borussia's strategies can improve the brazilian soccer teams average attendance.

Key-words

Strategic planning, sports marketing, Brazilian soccer teams, soccer stadiums, case, Borussia Dortmund, Flamengo, Vasco, Fluminense, Botafogo. 


\section{Sumário}

1 O tema e o problema de estudo 1

1.1. Introdução 1

1.2. Objetivo do estudo 3

1.3. Objetivos intermediários do estudo 4

1.4. Delimitação do estudo 4

1.5. Justificativa e relevância do estudo 4

2 Revisão de Literatura 6

2.1. O Futebol Brasileiro 6

2.1.1. A Lei Pelé 6

2.2. O Consumidor Esportivo 7

2.3. O Planejamento Estratégico 10

$\begin{array}{ll}\text { 2.4. As cinco forças de Porter } & 10\end{array}$

3 Métodos e procedimentos de coleta e de análise de dados do estudo 13

3.1. Procedimentos e instrumentos de coleta de dados utilizados no estudo 13

3.2. Formas de tratamento e análise dos dados coletados para o estudo 13

4 Apresentação e análise dos resultados 15

4.1. Estudo de caso: Borussia Dortmund 15

4.1.1. O contexto da crise financeira 15

4.1.2. A reestruturação 16

4.1.3. O BVB e a divisão das torcidas alemãs 19

4.1.4. As cinco forças de Porter aplicadas no BVB 21

4.2. Pesquisa com torcedores 24

4.2.1. Perfil dos torcedores 25

$\begin{array}{ll}\text { 4.2.2. Percepção sobre o elenco } & 27\end{array}$

4.2.3. Percepção sobre o conforto 28

$\begin{array}{ll}\text { 4.2.3.1. Segurança } & 28\end{array}$ 
4.2.3.2. Acesso 29

4.2.4. Percepção sobre o preço dos ingressos 31

4.2.5. Percepção sobre as campanhas aos torcedores 34

4.3. Pesquisa com um gestor de futebol 38

4.4. Análise das pesquisas 39

5 Conclusões e recomendações para novos estudos 46

5.1. Sugestões e recomendações para novos estudos 46

6 Referências Bibliográficas 48

$\begin{array}{ll}\text { Anexo } 1 & 52\end{array}$

$\begin{array}{lr}\text { Anexo } 2 & 53\end{array}$

\section{Lista de figuras}

Figura 1: Influências no comportamento do consumidor esportivo ....................... 8

Figura 2: As cinco forças de Porter ............................................................ 11

Figura 3: Preferência da torcida alemã por região ........................................ 20

Figura 4: Qual seu time de futebol?......................................................... 25

Figura 5: Perfil dos respondentes.............................................................. 26

Figura 6: Grau de importância da presença de ídolos ..................................... 27

Figura 7: Grau de importância da situação do time no campeonato ................... 28

Figura 8: Grau de importância da segurança............................................... 28

Figura 9: Grau de importância do acesso ..................................................... 30

Figura 10: Grau de importância do preço dos ingressos ................................. 32

Figura 11: Grau de importância das campanhas para os torcedores................. 35

Figura 12: Visão geral da importância dos itens analisados ........................... 40 


\section{Lista de Tabelas}

Tabela 1: Ranking da média de público dos campeonatos nacionais .................. 1

Tabela 2: Os 100 Clubes com maior média de público $\left(1^{\circ}\right.$ ao $\left.10^{\circ}\right)$...................... 2

Tabela 3: Colocação dos clubes brasileiros de maior média de público .............. 3

Tabela 4: Escala do envolvimento dos torcedores ...................................... 9

Tabela 5: Segurança x Frequência nos estádios ........................................... 29

Tabela 6: Acessibilidade x Time ................................................................ 30

Tabela 7: Preço do ingresso x Frequência nos estádios ................................ 32

Tabela 8: Campanha para torcedores x Sócio Torcedor ................................. 35

Tabela 9: Sócio Torcedor $x$ Time.............................................................. 36

Tabela 10: Percepção por time ................................................................ 42 


\section{0 tema e o problema de estudo}

\subsection{Introdução}

Conhecido como "esporte das multidões", o futebol no Brasil já não consegue ser tão atrativo aos torcedores como já foi num passado não muito distante. Segundo o levantamento recente realizado pela Pluri Consultoria (2013/2014), a média de público do Campeonato Brasileiro (Brasileirão) foi apenas a $15^{\mathrm{a}}$ do mundo, atrás de campeonatos nacionais de países de pouca ou até nenhuma tradição no esporte, como Estados Unidos ( $\left.9^{\circ}\right)$, Japão (12ํ) e China $\left(10^{\circ}\right)$, e até mesmo dos campeonatos da $2^{\mathrm{a}}$ divisão da Inglaterra (13ํ) e Alemanha $\left(11^{\circ}\right)$.

Tabela 1: Ranking da média de público dos campeonatos nacionais Fonte: Pluri Consultoria (2014)

\begin{tabular}{|c|c|c|c|c|c|c|c|c|}
\hline $\begin{array}{l}\text { Rank } \\
2014\end{array}$ & $\begin{array}{l}\text { Rank } \\
2013\end{array}$ & $\begin{array}{l}\text { Rank } \\
2012\end{array}$ & Pais & Campeonato & $\begin{array}{c}\text { Média de } \\
\text { Público } \\
2014 / \\
2013\end{array}$ & $\begin{array}{c}\text { Variação } \\
\% 2014- \\
2013\end{array}$ & $\begin{array}{c}\text { Média de } \\
\text { Público } \\
2013 / \\
2012\end{array}$ & $\begin{array}{c}\text { Média de } \\
\text { Público } \\
2012 / \\
2011\end{array}$ \\
\hline 1 & 1 & 1 & Alemanha & 1.Bundesliga & 43.173 & $1 \%$ & 42.646 & 45.083 \\
\hline 2 & 2 & 2 & Inglaterra & Premier League & 36.589 & $2 \%$ & 35.921 & 34.604 \\
\hline 3 & 3 & 3 & Espanha & Primera División & 26.867 & $-6 \%$ & 28.616 & 28.400 \\
\hline 4 & 5 & 5 & Itália & Serie A & 23.365 & $1 \%$ & 23.053 & 21.921 \\
\hline 5 & 4 & 4 & México & Liga MX Apertura & 22.939 & $-5 \%$ & 24.245 & 25.343 \\
\hline 6 & 8 & 7 & França & Ligue 1 & 20.693 & $8 \%$ & 19.191 & 18.863 \\
\hline 7 & 6 & 9 & Argentina & Inicial / Final & 20.599 & $0 \%$ & 20.571 & 18.216 \\
\hline 8 & 7 & 6 & Holanda & Eredivisie & 19.289 & $-2 \%$ & 19.737 & 19.458 \\
\hline 9 & 9 & 8 & EUA & MLS & 18.743 & $-1 \%$ & 18.845 & 18.700 \\
\hline 10 & 10 & 11 & China & Super League & 18.571 & $-1 \%$ & 18.740 & 17.675 \\
\hline 11 & 12 & 12 & Alemanha & 2.Bundesliga & 17.491 & $1 \%$ & 17.271 & 17.212 \\
\hline 12 & 13 & 13 & Japão & J. League 1 & 17.160 & $4 \%$ & 16.434 & 16.572 \\
\hline 13 & 11 & 10 & Inglaterra & Championship & 16.438 & $-7 \%$ & 17.660 & 17.899 \\
\hline 14 & 16 & 15 & Turquia & Süper Lig & 15.014 & $16 \%$ & 12.984 & 14.058 \\
\hline 15 & 17 & 14 & Brasil & Brasileirão A & 14.951 & $15 \%$ & 12.971 & 14.897 \\
\hline
\end{tabular}


Falando em Alemanha, depois da dolorosa eliminação por $7 \times 1$ sofrida pela Seleção Brasileira na Copa do Mundo de 2014, muito se falou da estrutura do futebol brasileiro e um dos pontos mais citados foi sobre a média de público nos estádios, onde os alemães são os campeões por três anos consecutivos quando se trata do assunto (apresentando uma média de 43.173 pessoas na última temporada da Bundesliga - o campeonato alemão -, contra apenas 14.951 do Brasileirão).

Segundo outro relatório realizado recentemente (o ranking mundial de público dos clubes de futebol nos estádios) pela Pluri Consultoria (2013/2014), o clube alemão Borussia Dortmund continua sendo, pelo terceiro ano consecutivo, o clube que mais leva torcedores ao estádio em todo o mundo, com um público médio de 80.297 pessoas por jogo na última temporada da Bundesliga, 100\% de ocupação do estádio e todos os jogos com ingressos esgotados antecipadamente. Dos 100 primeiros colocados deste ranking, os alemães são líderes com 25 representantes (sendo que 6 estão entre os 10 primeiros, e um está na $2^{\mathrm{a}}$ divisão), contra apenas 2 representantes do Brasil: o Cruzeiro é o $70^{\circ}$ com 28,9 mil torcedores por jogo, seguido pelo Santa Cruz em 89ำ com 26,6 $\mathrm{mil} /$ jogo.

Tabela 2: Os 100 Clubes com maior média de público (1ํao 10) Fonte: Pluri Consultoria (2014)

\begin{tabular}{|c|c|c|c|c|c|c|c|c|c|}
\hline 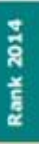 & 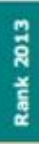 & $\begin{array}{l}\text { क्ष } \\
\text { है } \\
\text { है }\end{array}$ & Clube & País & $\begin{array}{l}\text { Média de } \\
\text { Público } \\
2014- \\
2013\end{array}$ & $\begin{array}{c}\text { \% de } \\
\text { ocupação } \\
\text { médio }\end{array}$ & $\begin{array}{c}\text { Média de } \\
\text { Público } \\
2013- \\
2012\end{array}$ & $\begin{array}{c}\text { Média de } \\
\text { Público } \\
2012- \\
2011\end{array}$ & $\begin{array}{c}\text { Variaçăo } \\
\%\end{array}$ \\
\hline 1 & 1 & 1 & $\begin{array}{l}\text { Borussia } \\
\text { Dortmund }\end{array}$ & Alemanha & 80.297 & $100 \%$ & 80.558 & 80.552 & $0 \%$ \\
\hline 2 & 2 & 2 & $\begin{array}{l}\text { Manchester } \\
\text { United }\end{array}$ & Inglaterra & 75.207 & $99 \%$ & 75.530 & 75.387 & $0 \%$ \\
\hline 3 & 3 & 3 & Barcelona & Espanha & 72.116 & $73 \%$ & 71.681 & 74.582 & $1 \%$ \\
\hline 4 & 5 & 4 & Real Madri & Espanha & 71.558 & $84 \%$ & 69.262 & 72.316 & $3 \%$ \\
\hline 5 & 4 & 5 & $\begin{array}{l}\text { Bayern } \\
\text { Munique }\end{array}$ & Alemanha & 71.000 & $100 \%$ & 70.954 & 69.053 & $0 \%$ \\
\hline 6 & 6 & 6 & Schalke 04 & Alemanha & 61.569 & $100 \%$ & 61.171 & 61.218 & $1 \%$ \\
\hline 7 & 7 & 7 & Arsenal & Inglaterra & 60.013 & $99 \%$ & 60.079 & 60.000 & $0 \%$ \\
\hline 8 & 12 & 12 & $\begin{array}{l}\text { Borussia } \\
\text { Mönch. }\end{array}$ & Alemanha & 52.239 & $97 \%$ & 49.557 & 51.882 & $5 \%$ \\
\hline 9 & 36 & 10 & Hertha Berlin & $\begin{array}{c}\text { Alemanha } \\
\left(2^{8}\right)\end{array}$ & 51.889 & $70 \%$ & 40.021 & 53.449 & $30 \%$ \\
\hline 10 & 8 & 11 & Hamburgo & Alemanha & 51.825 & $98 \%$ & 52.931 & 53.436 & $-2 \%$ \\
\hline
\end{tabular}

Apesar da tradição de alguns clubes brasileiros, muitos deles aparecem apenas quando se amplia a lista para 200 times de maiores púbicos. Entre esses 
clubes encontram-se: Corinthians (103우 24,4 mil/jogo), Flamengo (111ㅇ; 23,4 mil/jogo), São Paulo (113ㅇ; 23,1 mil/jogo), Grêmio (148o; 19,8 mil/jogo),

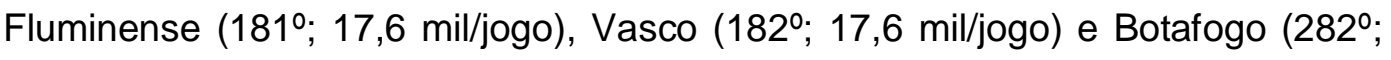
$12,7 \mathrm{mil} /$ jogo).

Tabela 3: Colocação dos clubes brasileiros de maior média de público - Fonte: Pluri Consultoria (2014)

\begin{tabular}{|c|c|c|c|c|c|c|c|c|c|}
\hline 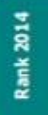 & 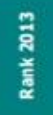 & 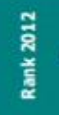 & Clube & País & $\begin{array}{c}\text { Média de } \\
\text { Público } \\
2013- \\
2012\end{array}$ & $\begin{array}{c}\text { \% de } \\
\text { ocupaçăo } \\
\text { médio }\end{array}$ & $\begin{array}{l}\text { Média de } \\
\text { Público } \\
2013- \\
2012\end{array}$ & $\begin{array}{l}\text { Média de } \\
\text { Público } \\
2012- \\
2011\end{array}$ & $\begin{array}{c}\text { Variação } \\
\%\end{array}$ \\
\hline 70 & 374 & 421 & Cruzeiro & Brasil & 28.911 & $50 \%$ & 11.677 & 10.377 & $148 \%$ \\
\hline 89 & 95 & 39 & Santa cruz & Brasil $\left(3^{a}\right)$ & 26.578 & $44 \%$ & 24.347 & 36.916 & $9 \%$ \\
\hline 103 & 91 & 65 & Corinthians & Brasil & 24.441 & $64 \%$ & 25.222 & 29.424 & $-3 \%$ \\
\hline 111 & - & - & Flamengo & Brasil & 23.385 & $55 \%$ & 12.250 & 16.985 & $91 \%$ \\
\hline 113 & 98 & 112 & São Paulo & Brasil & 23.115 & $34 \%$ & 24.298 & 21.476 & $-5 \%$ \\
\hline 148 & 105 & 184 & Grêmio & Brasil & 19.764 & $43 \%$ & 23.530 & 16.412 & $-16 \%$ \\
\hline 149 & 150 & - & $\begin{array}{l}\text { Sampaio } \\
\text { Correa }\end{array}$ & Brasil $\left(3^{a}\right)$ & 19.664 & $49 \%$ & 19.527 & 3.742 & $1 \%$ \\
\hline 169 & 158 & 100 & Bahia & Brasil & 18.449 & $57 \%$ & 18.981 & 22.741 & $-3 \%$ \\
\hline 181 & - & - & Fluminense & Brasil & 17.637 & $37 \%$ & 12.644 & 11.569 & $39 \%$ \\
\hline 182 & - & - & Vasco & Brasil & 17.618 & $64 \%$ & 7.559 & 13.866 & $133 \%$ \\
\hline 217 & 194 & 214 & Sport & Brasil $\left(2^{a}\right)$ & 15.686 & $45 \%$ & 17.811 & 17.204 & $-12 \%$ \\
\hline 235 & - & - & Palmeiras & Brasil $\left(2^{a}\right)$ & 14.974 & $53 \%$ & 11.983 & 12.586 & $25 \%$ \\
\hline 239 & - & - & Vitória & Brasil & 14.780 & $41 \%$ & 16.192 & 11.850 & $-9 \%$ \\
\hline 243 & - & - & Coritiba & Brasil & 14.651 & $39 \%$ & 12.579 & 17.894 & $16 \%$ \\
\hline 262 & - & - & Ceará & Brasil $\left(2^{3}\right)$ & 13.837 & $47 \%$ & 8.853 & 12.699 & $56 \%$ \\
\hline 271 & - & - & Fortaleza & Brasil $\left(3^{a}\right)$ & 13.385 & $45 \%$ & 14.574 & 8.503 & $-8 \%$ \\
\hline 282 & - & - & Botafogo & Brasil & 12.685 & $33 \%$ & 8.522 & 13.080 & $49 \%$ \\
\hline 283 & - & - & Goiás & Brasil & 12.680 & $41 \%$ & 14.185 & 8.059 & $-11 \%$ \\
\hline 311 & - & - & Criciúma & Brasil & 11.548 & $60 \%$ & 10.290 & 5.981 & $12 \%$ \\
\hline 314 & 187 & 304 & Atlético-MG & Brasil & 11.436 & $54 \%$ & 18.274 & 14.100 & $-37 \%$ \\
\hline 315 & - & - & Vila Nova-GO & Brasil $\left(3^{a}\right)$ & 11.315 & $51 \%$ & 4.114 & 5.146 & $175 \%$ \\
\hline 344 & - & - & Santos & Brasil & 10.405 & $62 \%$ & 8.108 & 8.892 & $28 \%$ \\
\hline
\end{tabular}

Considerando o sucesso de público alcançado pelo futebol alemão e seus clubes, esta pesquisa busca entender o seguinte questionamento: Quais características da estratégia do clube alemão Borussia Dortmund podem ser aplicadas nos clubes de futebol do Brasil para que estes consigam alavancar a média de público em seus estádios?

\subsection{Objetivo do estudo}

O presente trabalho tem como objetivo analisar quais estratégias aplicadas pelo Borussia Dortmund, clube que mais consegue trazer seus torcedores para o 
estádio no mundo, podem ser usadas por clubes brasileiros para que mantenham seus estádios cheios, como o clube alemão faz com excelência.

\subsection{Objetivos intermediários do estudo}

Para se atingir o objetivo final proposto, esse estudo prevê como objetivos intermediários a serem alcançados:
(6) Analisar o caso de sucesso do Borussia Dortmund
(6) Comparar as estratégias usadas pelo Borussia Dortmund com as estratégias aplicadas por clubes do Rio de Janeiro

\subsection{Delimitação do estudo}

Este estudo está delimitado em analisar as estratégias do Borussia Dortmund a partir de 2003, período em que o cenário do clube mudou drasticamente (ficando próximo a declarar falência) e um trabalho de reformulação das estratégias começou a ser realizado. Apesar do clube trabalhar em linhas distintas dentro de seu planejamento estratégico, o estudo levará em consideração apenas a linha estratégica de marketing.

Não foram levados em consideração nesse estudo os dados de público dos clubes cariocas durante o Campeonato Estadual e Copa do Brasil, por estes não serem realizados completamente no modelo de pontos corridos (como é o caso do Brasileirão).

Para analisar os dados de público do Borussia Dortmund, foi levado em consideração o público de seu estádio, Signal Iduna Park, durante a Bundesliga (o Campeonato Alemão).

\subsection{Justificativa e relevância do estudo}

É um estudo importante para os clubes brasileiros e seus gestores, já que é apresentada uma relação entre um caso de sucesso no futebol mundial e alguns dos principais clubes do Brasil.

Com o estudo, os gestores de marketing dos clubes têm a possibilidade de melhorar suas estratégias, cruzar suas principais ações com a real demanda e expectativa do torcedor e ajudar a trazer de volta a atratividade que o futebol nacional tinha no passado. Além disso, o torcedor vai poder usufruir de melhores 
benefícios caso o seu clube estruture suas ações de marketing para uma forma mais direcionada para o que ele espera.

Academicamente, apresenta-se um caso de um produto(s) (os estádios de futebol no Brasil), que apesar de possuir um grande potencial pela cultura do brasileiro com o futebol, ainda não é devidamente explorado pelos gestores de clubes. 


\section{Revisão de Literatura}

\subsubsection{Futebol Brasileiro}

O Brasil é um país de clima favorável à prática esportiva, com uma população jovem apaixonada por esportes e competições.

A transformação que o futebol brasileiro vem passando está obrigando os clubes a serem cada vez mais profissionais, pois agora essas entidades devem ser tratadas como verdadeiras empresas.

\subsubsection{A Lei Pelé}

De acordo com o relatório anual da FIFA, o Brasil é o país que mais exporta jogadores jovens em todo o mundo. De janeiro de 2012 a junho de 2014, 109 atletas menores de vinte anos saíram do Brasil para tentar a sorte no futebol europeu.

Muitas dessas saídas de jogadores se devem à Lei Pelé, criada em 1998 e que terminou com o passe dos jogadores no Brasil. O passe era um instrumento jurídico que prendia o jogador ao clube além do seu contrato de trabalho por tempo indeterminado. Quando existia o passe, os jogadores só poderiam deixar seus clubes caso fossem autorizados pelos clubes, mesmo sem ter um contrato de trabalho com qualquer clube. Na época, não era estranho um jogador ficar parado esperando que algum outro clube interessado se dispusesse a pagar o que o clube dono de seu passe queria.

Com o fim do passe, o vínculo entre jogador e clube passou a ser exclusivamente o seu contrato de trabalho (cada qual com seus direitos federativos e econômicos), que pode ter uma duração de até 5 anos. Hoje o clube é dono dos direitos federativos, mas os direitos econômicos podem pertencer a empresários e investidores. Com isso os atletas deixaram de ser reféns dos desejos dos dirigentes de seus clubes, mas ficam muitas vezes submetidos à influência dos agentes. Há casos onde os empresários são acusados por muitos clubes de forçarem a saída de jovens talentos para se beneficiarem com o dinheiro da venda. 
"Antes, o jogador ficava cinco, dez anos jogando no mesmo clube. Hoje não é mais assim. Muito empresário leva o jogador para a Ásia, Rússia e esquece ele lá, faz o que quiser. Então tem essa parte ruim, que o clube não é mais dono do jogador, o empresário é que manda. " (Pelé, 2014)

Apesar da Lei Pelé ter ajudado a profissionalizar o esporte no Brasil, muitas críticas são feitas até hoje em decorrência desta nova realidade que vive o futebol brasileiro: esse maçante êxodo de jogadores acaba enfraquecendo não só os clubes formadores, mas também o campeonato nacional como um todo.

"Quem ganhou com a Lei Pelé foram os empresários e os clubes europeus, que, desde 2001, não precisam mais passar pelo incômodo de negociar com outros clubes: simplesmente mandam representantes ao Brasil, que colhem os jogadores na fonte, isto é: nas salas de suas casas, fazendo contratos diretamente com os pais ou com atravessadores espertalhões. " (David Coimbra, 2014)

\subsubsection{Consumidor Esportivo}

Pitts e Stotlar (2002) destacam que o consumidor esportivo pode ser alocado em três tipos de segmentos:

(e) Prática esportiva - que é oferecida ao consumidor como produto de participação e/ou entretenimento;

(9) Produtos esportivos - produtos e serviços, como equipamentos esportivos e serviços médicos, ofertados aos consumidores para a prática de esportes;

(6) Promoção esportiva - produtos e serviços que são ofertados para promover o esporte, incluindo eventos, brindes e patrocínios, por exemplo.

Para cada um desses segmentos o consumidor esportivo apresenta motivadores distintos, o que tende a não ocorrer na maioria dos produtos ou serviços ofertados por outros setores. Os autores ainda destacam o vasto conjunto de produtos oferecidos na indústria do esporte, o que confirma o elevado nível de complexidade envolvido nas escolhas dos seus consumidores.

Seguindo essa linha de pensamento, Mullin, Hardy e Sutton (2004) enfatizam que "o consumidor esportivo apresenta-se mais suscetível às influências tanto ambientais como individuais".

$\mathrm{Na}$ figura 1 pode ser conferido um esboço das influências no comportamento desse tipo de consumidor. 


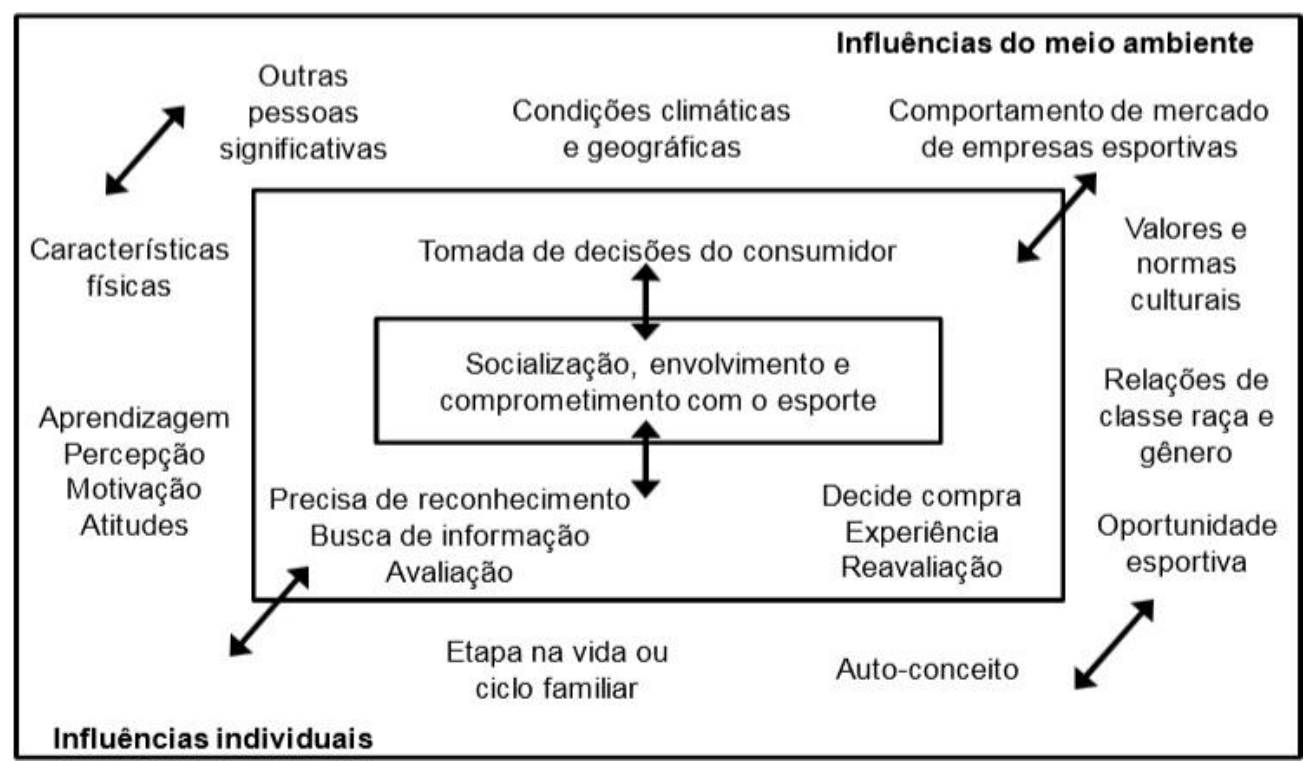

Figura 1: Influências no comportamento do consumidor esportivo - Fonte: Mullin, Hardy e Sutton (2004, p. 53)

Esse modelo enfatiza a importância das influências individuais, compostas por:

6) Características físicas: podem impactar na escolha do esporte a ser praticado;

6) Aprendizagem, motivação e atitudes: relacionadas ao lado afetivo, incluindo a preferência por equipe, esporte ou esportista;

6) Etapa na vida: fator que pode interferir tanto no esporte a ser praticado como na escolha de produtos ou serviços esportivos

Ao se analisar as influências ambientais, destacam-se alguns fatores que afetam o consumidor esportivo, como:

6) Oportunidade esportiva: determinante para influenciar na preferência entre as diferentes modalidades esportivas;

6) Influências sociais: ainda mais importante quando se consideram os esportes coletivos;

(6) Condições climáticas ou geográficas: que possibilitam ou impedem a prática de determinadas modalidades esportivas

Segundo Rein, Kotler e Shields (2008), a crescente concorrência e esportes novos ou emergentes cooperam para fragmentar o mercado esportivo, 
dificultando a atuação das organizações do setor. Eles atribuem as seguintes características a esse mercado dinâmico:

6) Ambiente altamente competitivo;

(6) Torcedores com expectativas elevadas;

(6) Conflito entre o conceito de esporte como negócio e como competição;

(6) Surgimento de novas tecnologias;

(6) Interesses cada vez mais individuais dos consumidores;

6) Mudanças na estrutura e no comportamento das famílias;

(6) Falta de tempo dos consumidores

Por fim, Morgan e Summers (2008, p. 131) afirmam que "os consumidores esportivos podem ser pesquisados, segmentados, perfilados e definidos como alvo, mas a essência do que querem pode ser um mistério! Isso ocorre porque o que desejam é a imprevisibilidade. Eles querem competição!" Essa característica transforma 0 entendimento do comportamento do consumidor esportivo em um grande desafio para os profissionais de marketing.

Em se tratando de perfil, Rein, Kotler e Shields (2008) atribuem os seguintes perfis aos consumidores esportivos, a ser conferido na Tabela 4:

Tabela 4: Escala do envolvimento dos torcedores - Fonte: adaptado de Rein, Kotler e Shields (2008, p. 94)

\begin{tabular}{|l|l|}
\hline Fanáticos & $\begin{array}{l}\text { Os mais persistentes e participantes, tendem a se identificar totalmente com o esporte, rara- } \\
\text { mente faltam com seu apoio à equipe preferida, tanto pessoalmente como financeiramente }\end{array}$ \\
\hline Conhecedores & $\begin{array}{l}\text { Fãs que têm amplo acesso e intensa participação nos meandros do mundo dos eventos } \\
\text { esportivos }\end{array}$ \\
\hline Agregados & $\begin{array}{l}\text { Torcedores que querem estar sempre junto das equipes e dos seus heróis e ter oportunidades } \\
\text { continuadas de trocar saudações com eles, ou concretizar outra experiência de interação }\end{array}$ \\
\hline Colecionadores & $\begin{array}{l}\text { Fãs sempre dispostos a pagar bem por produtos que de alguma forma simbolizem o esporte } \\
\text { preferido }\end{array}$ \\
\hline Gastadores & Pessoas dispostas a investir grande soma pelo prazer do esporte \\
\hline Curiosos & $\begin{array}{l}\text { Normalmente se relacionam com o esporte por meio da mídia, inclusive para acompanhá-lo, } \\
\text { sendo que raramente comparecem a algum evento esportivo }\end{array}$ \\
\hline Indiferentes & Pessoas que não tem interesse em esporte \\
\hline
\end{tabular}

Ainda pode-se destacar que "mesmo com alguns estudos analisando as características do consumidor esportivo, a literatura acadêmica de marketing ainda carece de pesquisas que envolvam exclusivamente o mercado esportivo, e que evitem utilizar as mesmas abordagens de estudos já existentes sobre outros tipos de consumidores. Esse tipo de abordagem generalista pode atrapalhar o 
conhecimento mais aprofundado sobre o consumidor esportivo." (Funk; Mahony; Havitz, 2003)

\subsubsection{Planejamento Estratégico}

Segundo Kotler (1992), "o planejamento estratégico se trata de uma metodologia gerencial que permite estabelecer a direção a ser seguida pela organização, visando um maior grau de interação com o ambiente. "Segundo Maximiano (2006), "o processo de planejamento estratégico compreende a tomada de decisões sobre qual o padrão de comportamento que a organização pretende seguir, produtos e serviços que pretende oferecer, e mercados e clientes que pretende atingir."

Dessa forma, pode-se dizer que o planejamento estratégico é o processo onde uma organização é analisada sob diferentes ângulos, direcionando suas ações de acordo com o rumo que ela decide tomar no mercado onde atua. Segundo Drucker (1984), “o planejamento estratégico é um processo contínuo e sistemático, que possui o maior conhecimento possível acerca do futuro. Tomar decisões que envolvem riscos, organizar sistematicamente as ações necessárias para uma boa execução das decisões e retroalimentar e medir os efeitos dessas decisões são tarefas que fazem parte do planejamento estratégico de uma organização."

Conclui-se que o planejamento estratégico deve estar alinhado e ser executado de acordo com a missão e valores da empresa, sendo importante a participação dos gestores durante o processo de criação e supervisão do planejamento estratégico. Uma empresa que possui um bom planejamento consegue projetar suas estratégias de forma eficaz para aumentar seu espaço no mercado onde atua, uma vez que o planejamento estratégico a permite enxergar quais ações e de que forma devem ser tomadas, sendo crucial para o seu sucesso.

\subsection{As cinco forças de Porter}

Segundo uma publicação da Smart Consultoria (2014), para se desenvolver um planejamento eficiente, uma empresa (assim como um clube de futebol) deve analisar cinco fatores, denominados "forças competitivas", onde uma depende do microambiente, interno, e as demais dependem do macro 
ambiente, externas, em relação ao setor de atuação. Qualquer mudança em uma das forças requer uma nova pesquisa, de forma a reavaliar o mercado. Este modelo de análise é conhecido como "Cinco forças de Porter" e permite analisar o grau de atratividade da empresa em relação aos seus concorrentes, conforme mostra a Figura 2:

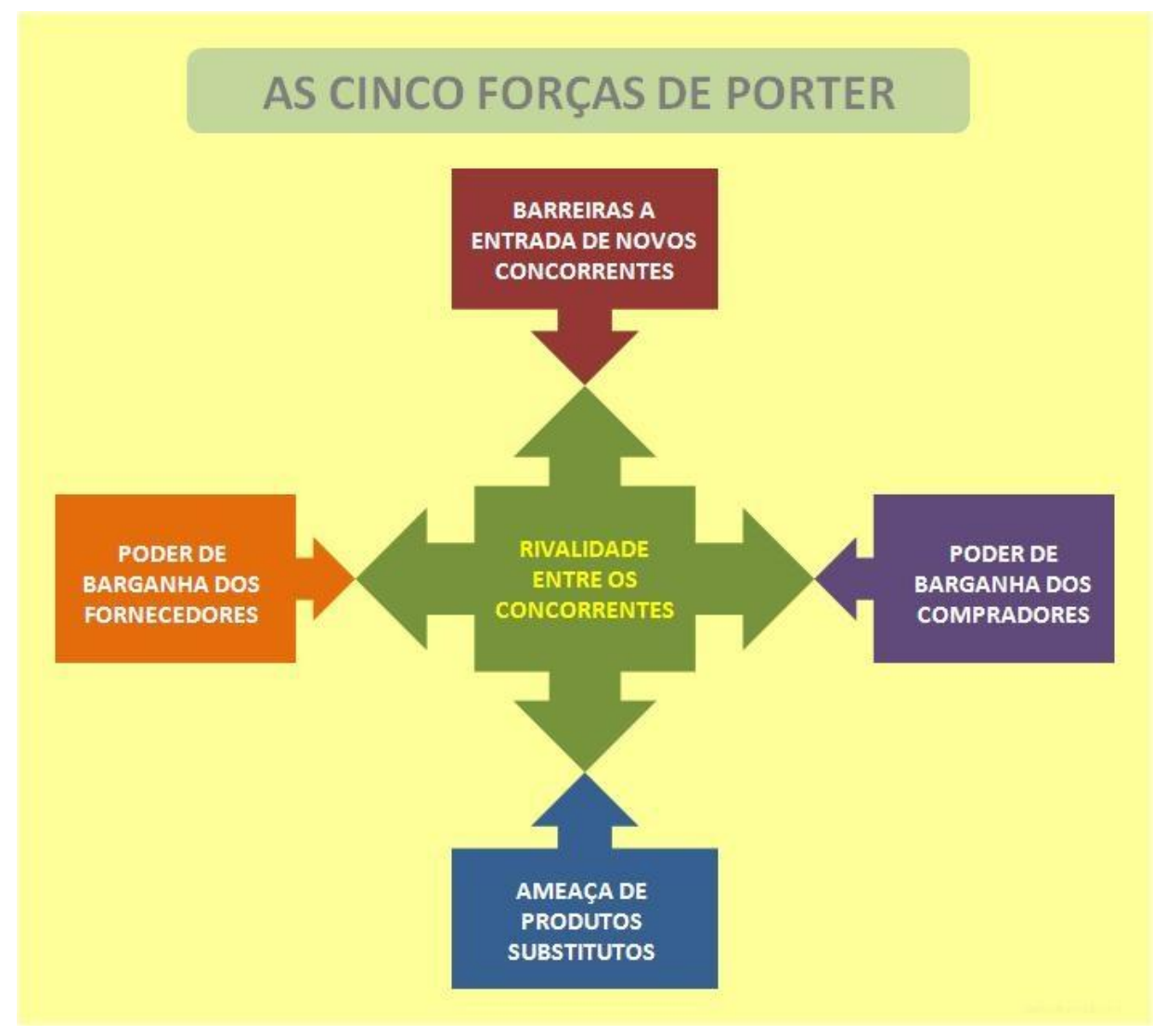

Figura 2: As cinco forças de Porter - Fonte: Administradores.com (2011)

Rivalidade entre os concorrentes - Avalia-se a competitividade do mercado levando em consideração aspectos como quantidade, Market share e diversidade dos concorrentes diretos.

Barreiras à entrada de novos concorrentes - "Além de ser necessário observar as atividades das empresas concorrentes, a ameaça da entrada de novos participantes depende das barreiras existentes contra sua entrada, além do poder de reação das organizações já constituídas". (Serra, Torres \& Torres, 2004). Aqui é avaliada a dificuldade de novas empresas entrarem em determinado mercado, levando em consideração a necessidade de capital inicial 
para começar seu negócio, os custos de distribuição e acesso aos canais de distribuição.

Poder de barganha dos compradores - Avalia o poder de negociação dos compradores, onde avalia-se o volume de compras, as quantidades de fornecedores e seus custos de mudança e a força dos produtos substitutos.

Poder de barganha dos fornecedores - Avalia o poder de negociação dos fornecedores, onde a quantidade de fornecedores existentes e o custo para a mudança de fornecedor são levadas em consideração para avaliar sua força.

Ameaça de produtos substitutos - São aqueles que não são iguais ao seu produto, mas atendem à uma mesma necessidade. É analisada a relação preço/rendimento, os custos de mudança para o comprador sua propensão em trocar de produto.

Segundo uma publicação no site Executivo Inteligente (2010), esses cinco fatores influenciam de forma importante na elaboração estratégica das empresas que, por sua vez, devem estar atentas a essas informações referentes ao ambiente interno e externo a ela, pois no mercado globalizado, as informações são um fator que deve ser levado em consideração como um dos principais na gestão estratégica de um negócio. 


\section{Métodos e procedimentos de coleta e de análise de dados do estudo}

\subsection{Procedimentos e instrumentos de coleta de dados utilizados no estudo}

Considerando as características da pesquisa, optou-se por um estudo de múltiplos casos, permitindo assim um conhecimento aprofundado do problema em questão.

Segundo Chizzotti (1995, p. 102), estudo de caso "é a pesquisa para coleta e registro de dados de um ou vários casos, para organizar um relatório ordenado e crítico ou avaliar analiticamente a experiência com o objetivo de tomar decisões ou propor ação transformadora. "

Segundo Gil (1987, p. 58), "é o estudo profundo e exaustivo de um ou de poucos objetos para permitir um amplo e detalhado conhecimento."

Para este estudo foram utilizados diversos tipos de fontes, procurando assim reduzir viés causado sem o cruzamento de informações. Nesse sentido, foi realizado um levantamento documental dos casos, entrevistas em profundidade com pessoas com conhecimento da administração estratégica dos clubes estudados e, finalmente, uma pesquisa quantitativa com pessoas buscando compreender sua percepção sobre o tema.

\subsection{Formas de tratamento e análise dos dados coletados para o estudo}

A pesquisa quantitativa foi realizada através de uma amostra por conveniência, onde o foco era entender a perspectiva dos torcedores dos clubes cariocas. Foram obtidas 108 respostas no questionário enviado.

Em complemento, foi realizada uma entrevista em profundidade com um gestor de futebol para que fosse possível compreender a realidade de um clube de futebol brasileiro. Como se desejava ter a percepção de gestores dos clubes cariocas, foram enviados questionários a gestores de Flamengo, Fluminense, Vasco e Botafogo, mas apenas o gestor do Botafogo retornou o contato com as devidas respostas. 
Após a realização das etapas de pesquisa e estudo, foi feita uma análise cruzada das informações coletadas para poder identificar tendências onde se viu possível listar quais estratégias do Borussia Dortmund podem ser adotadas ou adaptadas no futebol brasileiro para alavancar a atratividade dos seus estádios de futebol, e consequentemente, do campeonato nacional. 


\section{Apresentação e análise dos resultados}

\subsection{Estudo de caso: Borussia Dortmund}

O Ballspiel-Verein Borussia 1909 e. V. Dortmund, mais conhecido por Borussia Dortmund (BVB), foi fundado em 19 de dezembro de 1909, sediado em Dortmund, na Renânia do Norte-Vestfália. O clube joga no Westfalenstadion, possui uma das maiores torcidas da Alemanha e a maior média de público no mundo, como já mencionado anteriormente.

\subsubsection{0 contexto da crise financeira}

Tudo se iniciou nos anos 90, quando a antiga diretoria do clube aurinegro adotou uma política de contratações caras e salários altíssimos. Durante essa década, essa política se mostrou ser eficaz com conquistas importantes como a Bundesliga em 1995 e 1996 e o maior título da história do clube: a Champions League (o maior campeonato disputado entre os times europeus e atrás somente da Copa do Mundo como o maior do mundo) de 1997.

Esse sucesso repentino fez com que a diretoria confiasse que essa era a forma correta de gerir o clube, bastaria seguir dessa forma que em questão de tempo o Borussia Dortmund estaria no mesmo patamar dos maiores clubes do mundo.

O clube se aproveitou de uma nova regra da liga alemã e passou a negociar ações na bolsa de valores de Frankfurt, rompeu o contrato com a Nike e passou a fabricar seus próprios uniformes, o que eliminaria o intermediário e, na teoria, geraria mais lucro. Com tanta glória dentro de campo e planos financeiros ousados, a diretoria fez um investimento arriscado.

Mas o retorno não foi como esperado. O clube chegou a ser campeão alemão novamente em 2002, mas fez campanhas fracas a nível internacional e deixou de ganhar o dinheiro que seria usado para pagar os altos investimentos realizados. O momento se mostrou ruim para abrir capital na bolsa e os 
resultados dentro de campo não ajudaram. O desentendimento com a Nike e a fabricação de material próprio deram mais despesas do que receita.

Com os graves problemas financeiros, o Borussia teve que vender 0 Westfalenstadion em 2002 para um grupo de investidores para aliviar suas dívidas. Três anos depois, recomprá-lo (mesmo que de forma parcial) se tornou a principal ação a ser tomada dentro do plano apresentado aos acionistas para sanear as finanças do clube.

Os dirigentes chegaram a um acordo para a recompra em parcelas, reforma e a venda dos naming rights da arena, ou seja, a atribuição do nome de uma empresa ao estádio em troca de pagamento. Até 2021, o estádio se chamará Signal Iduna Park, o nome de uma companhia de seguros alemã em troca de uma quantia estimada em 4,5 ou 5 milhões de euros anuais.

\subsubsection{A reestruturação}

Em 2006, houve uma mudança na diretoria. Reinhart Rauball assumiu como presidente e começou uma política de austeridade. Junto dele vieram o diretor executivo Hans-Joachim Watzke para comandar toda a parte financeira e administrativa e o diretor esportivo Michael Zorc, que foi o jogador que mais vezes vestiu a camisa do clube na história e fez toda sua carreira no time aurinegro, ou seja, era alguém muito identificado com o clube e que sabia com o que estava lidando.

Além deles, se juntaram Carsten Cramer, diretor de marketing e criador do slogan "Echte Liebe" (Amor verdadeiro em alemão - uma expressão usada para representar a paixão mútua entre clube e torcida) e o técnico Jürgen Klopp.

Um dos impactos sofridos pelo clube durante sua crise foi o desmanche de um elenco repleto de estrelas e salários altos demais para o clube administrar. Foi necessária uma nova filosofia da diretoria para a remontagem do elenco.

"Primeiro nós sentamos e demos uma olhada na situação. Aí nos perguntamos: O que esperam as pessoas desta parte do país, uma área de trabalhadores como o (Vale do) Ruhr? A resposta é que eles esperam um esforço honesto e que você dê seu máximo.

$E$ foi nisso que baseamos nossa nova filosofia. Nós definimos nosso mote: real e intenso. O futebol teria que ser intenso, e o clube teria que ser real. " (Hans-Joachim Watzke, 2013)

Com esse novo pensamento, a diretoria realizou uma busca por jogadores jovens e, em sua maioria, identificados com o clube. Um exemplo desses jogadores é Kevin Grosskreutz, que pode não ser um craque, mas é um bom 
jogador que corre muito, se esforça ao máximo e ainda é apaixonado pelo Borussia Dortmund. Grosskreutz nasceu em Dortmund, jogou nas categorias de base do clube e quando era jovem, foi dono de um carnê de ingressos para a arquibancada do Signal Iduna Park. Segundo Michael Zorc, "Construir um elenco com jovens aumenta o crédito com a torcida. Se eles erram, os fãs perdoam. ".

As mudanças no elenco não ficaram restritas apenas aos jogadores. Em 2008, um novo técnico foi escolhido para comandar o BVB: Jürgen Klopp. técnico comandou o modesto Mainz 05 em 2004 em sua estreia na 1ª divisão alemã. Além de conseguir manter o clube na $1^{\underline{a}}$ divisão naquele ano, alcançou 0 4 lugar no campeonato quatro anos depois, chamando a atenção dos dirigentes aurinegros.

"Michael Zorc (manager e ex-jogador do clube por 17 anos) e eu desenvolvemos uma filosofia na qual o time deveria jogar verticalmente, colocar o adversário permanentemente sob pressão. Em seguida foram selecionados os jogadores - é uma tarefa mais fácil quando se tem jovens e encontramos em Jürgen Klopp o treinador ideal" (Hans-Joachim Watzke, 2013)

Klopp se encaixou perfeitamente na nova filosofia do clube. Um treinador jovem, motivado e intenso. Em sua primeira entrevista coletiva, prometeu que os jogos do Borussia Dortmund seriam intensos e emocionantes, criando uma empatia com os torcedores, que logo se renderam ao estilo baseado na vontade de se doar por completo ao time. Um exemplo do seu trabalho está num pacto firmado com os seus jogadores: Pouco depois de sua chegada, o time chegou a ficar 6 jogos sem vencer. Quando o período de recesso de inverno se aproximava, Klopp prometeu aos jogadores mais três dias de férias caso eles, como uma equipe, corressem mais do que 118 quilômetros em cada um dos próximos 10 jogos. Essa foi uma forma de aumentar o esforço, de criar superioridade, de jogar um futebol mais intenso e vivo como os torcedores gostariam de ver. Os jogadores ultrapassaram essa marca na maioria dos jogos, mas não em todos. Klopp, porém, deu a folga a mais para eles.

Klopp desempenhou um importante papel nesta nova fase do clube, alinhando sua filosofia de trabalho com as expectativas dos torcedores, que mesmo que não vissem seu time ganhar todos os jogos, ao menos veriam uma equipe que se doava e se esforçava ao máximo. Coincidentemente, Klopp se tornou o técnico que conquistou o maior número de títulos e mais vezes comandou o clube em sete anos de serviço. 
O bom planejamento da diretoria aurinegra não se restringiu apenas à montagem do elenco nos tempos da crise. Pouco depois da janela de transferências ser aberta em 2013, o Borussia já era o quinto clube que mais havia investido em reforços, com um gasto de $€ 47,5$ milhões que garantiu as contratações dos jogadores Aubameyang, Papastathopoulos e Mkhitaryan, porém, é errado dizer que o clube abandonou sua política de austeridade.

Os aurinegros já haviam lucrado $€ 43,4$ milhões com a venda de atletas, o que permitiu a chegada destes novos jogadores. Papastathopoulos e Mkhitaryan estariam vindo como peças de reposição para desempenhar a função que Felipe Santana e Götze realizavam na equipe, respectivamente.

Prevendo perder um de seus principais jogadores, Robert Lewandowski, até a janela de transferências da temporada seguinte (o que acabou realmente se concretizando), a diretoria já se mexeu para trazer um substituto que pudesse ser preparado para exercer a mesma função: Aubameyang. O planejamento da diretoria se torna eficiente quando o clube já começa a preparar um novo jogador antes mesmo de uma perda se concretizar, permitindo que esse novo jogador tenha mais tempo para se adaptar à filosofia da equipe e aos seus colegas, minimizando a perda que o clube espera sofrer sem perder o rumo da equipe e de seus objetivos.

A atitude do BVB em planejar com antecedência suas contratações pode até não ser inédita (o Bayern de Munique também costuma fechar com seus reforços bem antes do mercado abrir), mas mostra como ter um planejamento estratégico bem definido é tão eficaz numa empresa como num clube de futebol.

"Um dos principais fatores para alcançar o objetivo de uma equipe é o planejamento. Da mesma forma que as empresas de outros setores organizam seus processos e métodos em torno das metas, os clubes de futebol, cada vez mais, devem assumir a importância do planejamento no desenvolvimento de suas equipes. As ações devem ser executadas de forma mais eficiente e com maior segurança, uma vez que as pessoas sabem exatamente o que devem fazer. " (Brunoro e Afif, 1997)

O resultado das novas ações dos dirigentes (que estão sendo aprofundadas a seguir) veio com o tempo: a diretoria cortou seus gastos, formou um elenco jovem e empenhado e manteve sua apaixonada torcida sempre próxima. Depois de duas boas colocações em 2008 e 2009, o BVB conseguiu conquistar o título da Bundesliga por dois anos seguidos em 2011 e 2012, retornando ao cenário mundial novamente. Chegou até mesmo a disputar uma final de Champions League na temporada de 2012/2013 contra o Bayern de 
Munique, mas nem mesmo as bonificações que o clube poderia receber com 0 título abalariam a política de austeridade da nova diretoria aurinegra.

"Nesse clube, apenas gastamos o dinheiro que ganhamos. Esse é o nosso paradigma, e é assim que continuará. Escolhemos uma rota sustentável e mesmo se vencermos a Champions não nos transformaremos." (HansJoachim Watzke, 2013)

Ainda hoje, o clube paga pelas dívidas contraídas na época que o levaram à crise financeira, mas se encontra em situação muito melhor e estável. Hoje, é novamente considerado como um dos 10 maiores clubes da Europa.

"Watzke me contava sobre o Dortmund antes da chegada de Jürgen Klopp, um clube desorientado internamente, $e$ isso afetou o funcionamento administrativo e o próprio rendimento em campo. Me veio à mente então a pergunta: 'O que realmente é o BVB? Qual a sua verdadeira identidade?'. Para chegar a uma resposta razoável, chamei amigos de fora que serviram de mediadores nessa história.

No final da reflexão e um processo até mesmo de auto-descoberta, vi que tudo se resumia em amor, um amor verdadeiro [Echte Liebe, em alemão]. Isso surgiu como a marca do clube, não é algo que seja mutável ou substituível.

O 'amor verdadeiro' está no DNA do Borussia Dortmund e não é uma campanha, é uma característica do clube." (Carsten Cramer, 2014)

\subsubsection{BVB e a divisão das torcidas alemãs}

A quantidade de títulos e a falta de concorrentes de peso na Baviera (segunda região mais populosa da Alemanha) fazem o Bayern Munique ser o clube mais popular da Alemanha. Os bávaros são representados por 9,3 milhões de pessoas, 24,9\% dos alemães que acompanham futebol. Já o Borussia Dortmund aparece com a segunda maior torcida, 5,7 milhões de torcedores, porém, o sucesso recente do clube torna o quadro mais favorável aos aurinegros.

Segundo uma pesquisa realizada pelo instituto Sport + Markt (2012), o BVB é o clube que tem conquistado o maior número de novos seguidores no país. Preferido na Renânia, pela primeira vez o clube apareceu entre os três mais populares em cinco das seis regiões alemãs, algo limitado ao Bayern. E o maior índice de ascensão dos aurinegros se dá na antiga Alemanha Oriental, porção do país mais carente de grandes clubes.

Os clubes mais tradicionais da Alemanha fazem valer o domínio em suas regiões. O Bayern Munique impera em $66 \%$ da torcida da Baviera; $60 \%$ dos fãs da Renânia do Norte-Vestfália apoiam Borussia Dortmund, Schalke 04 e Borussia Mönchengladbach; Werder Bremen e Hamburgo correspondem a 69\% 
da massa no Norte e o Stuttgart é representado por $40 \%$ da população em Baden-Württemberg, conforme se mostra na Figura 3.

Sobram Leste e Oeste, onde Bayern e Dortmund realmente se impulsionam nacionalmente. Embora não tenham vínculos com estas áreas, bávaros e aurinegros aparecem à frente mesmo dos clubes locais, como Eintracht Frankfurt e Hertha Berlim. Os bávaros vencem por $34 \%$ a $19 \%$ no Oeste, enquanto a vitória dos renanos é de $27 \%$ a $17 \%$ no Leste.

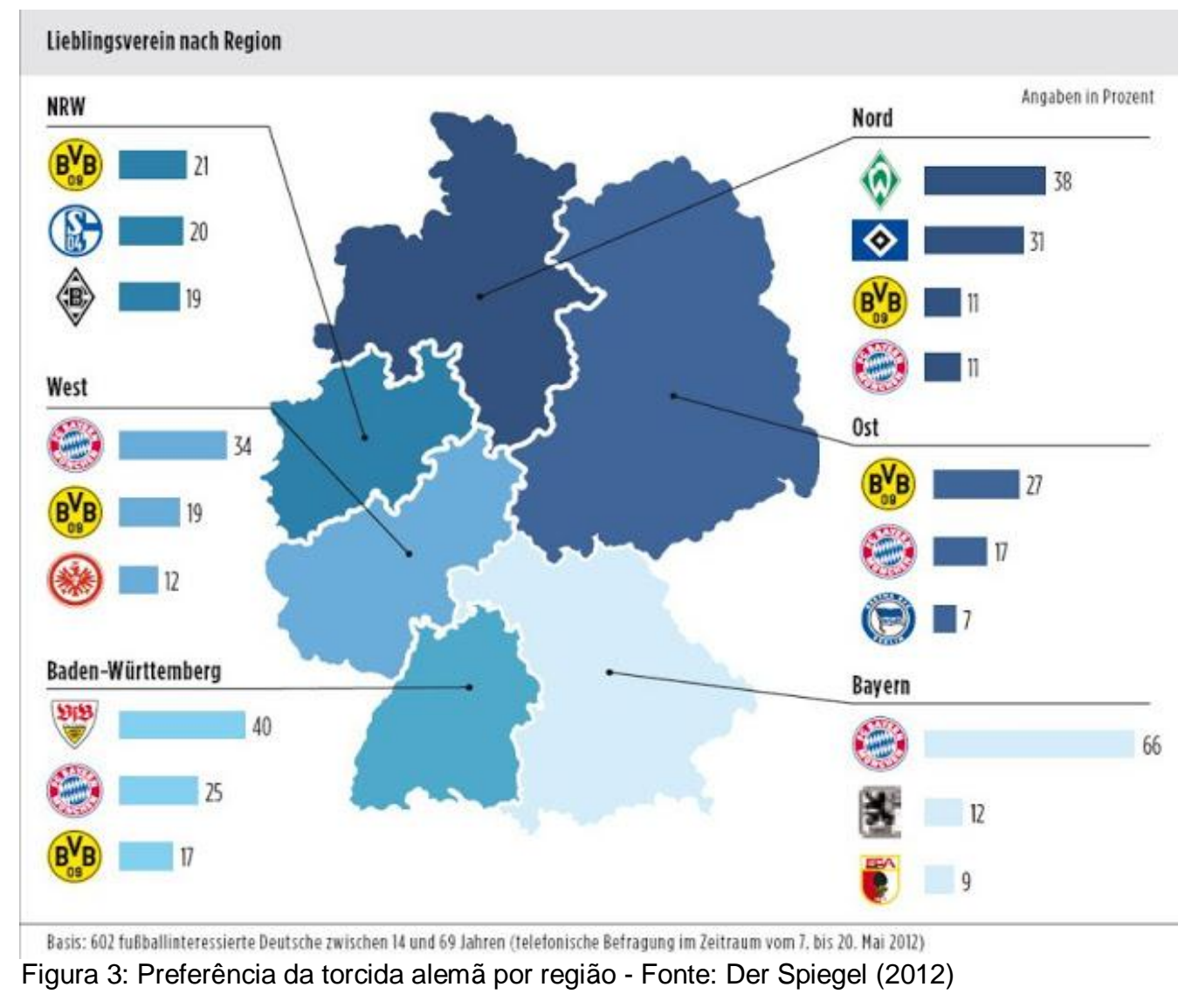

Não fosse a forte concorrência na Renânia do Norte-Vestfália, região alemã com mais clubes na primeira divisão, seria possível acreditar que o BVB pudesse competir de maneira igual com o Bayern.

A popularidade do Borussia Dortmund na Alemanha Oriental é explicada pela derrocada dos clubes da antiga república socialista. Desde que seu campeonato nacional foi extinto, em 1990/91, as equipes da região somaram apenas 23 aparições na primeira divisão alemã e somente quatro clubes foram capazes disso, sendo que o último a disputar a elite alemã foi em 2008/09.

Longe do topo da Bundesliga, os clubes orientais passaram a perder público nos estádios, dando margens para que o BVB ganhasse espaço no Leste. Segundo Carsten Cramer, a simpatia na Alemanha Oriental é explicada 
também pela origem de alguns ídolos. Principal jogador da seleção do país antes de sua extinção, Mathias Sammer fez carreira em Dortmund e até a temporada 2011/2012 se mantinha nos bastidores do clube. Recentemente, fizeram parte do elenco Leonardo Bittencourt e Chris Löwe, além de Marcel Schmelzer (que continua no clube), que nasceram na região.

\section{As cinco maiores torcidas da Alemanha em maio de 2012:}

$$
\begin{aligned}
& 1^{\circ}-\text { Bayern Munique }-9,3 \text { milhões }-24,9 \% \\
& 2^{\circ}-\text { Borussia Dortmund }-5,7 \text { milhões }-15,3 \% \\
& 3^{\circ}-\text { Werder Bremen }-3,3 \text { milhões }-8,9 \% \\
& 4^{\circ}-\text { Hamburg }-2,8 \text { milhões }-7,5 \% \\
& 5^{\circ}-\text { Borussia Mönchengladbach }-2,7 \text { milhões }-7,2 \%
\end{aligned}
$$

\section{As cinco maiores médias de público da Bundesliga 2012/13:}

$$
\begin{aligned}
& 1^{\circ}-\text { Borussia Dortmund }-80.558 \\
& 2^{\circ} \text { - Bayern Munique }-71.000 \\
& 3^{\circ} \text { - Schalke } 04-61.171 \\
& 4^{\circ} \text { - Hamburg }-52.931 \\
& 5^{\circ}-\text { Stuttgart }-50.106
\end{aligned}
$$

\subsubsection{As cinco forças de Porter aplicadas no BVB}

A seguir, pode-se verificar a análise do ambiente interno e externo do clube alemão através do modelo de cinco forças de Porter.

Barreiras à entrada de novos concorrentes - As barreiras de entrada para novos times de futebol na elite internacional são altíssimas, mas isso não significa que seja algo impossível. Alguns times europeus em baixa estão sendo comprados (na Europa, os clubes funcionam como empresas, diferente do Brasil) por bilionários e recebendo deles grandes quantias de dinheiro para contratações, tornando-se capazes de formar elencos fortes o suficiente para ingressar na elite mundial (casos como Chelsea, Manchester City e Paris SaintGermain, que no passado não tinham muita tradição e hoje disputam as principais competições possíveis). 
Esses "novos ricos" aumentaram consideravelmente o seu número de fãs pelo mundo devido às atuações recentes nas competições internacionais, porém, o BVB não está sujeito a essa perda, justamente por também se manter em alto nível e disputar as mesmas competições que esses times, além de nenhum desses "novos ricos" serem um time alemão.

"O principal requisito para ser conhecido fora da Alemanha é jogar bem em campeonatos internacionais, e temos feito isso. Apesar de todo o marketing, o futebol é sempre o centro das atenções, e o bom rendimento atrai o público. Ninguém se interessa por um time que joga mal." (Carsten Cramer, 2014)

No caso do BVB, como analisado, o que acontece é um aumento de fãs provenientes da região leste da Alemanha (a antiga Alemanha Oriental), devido ao fraco desempenho dos times dessa região na elite nacional e a identificação de jogadores e ídolos regionais com o time de Dortmund.

Poder de barganha dos compradores - O Borussia Dortmund é um clube que procura sempre mostrar o quanto seu torcedor é essencial para ele, mas isso não significa necessariamente que o poder deles seja alto.

A diretoria aurinegra possui uma filosofia de manter preços baixos nos ingressos, materiais esportivos e alimentos no estádio como uma forma de agradecimento por toda a contribuição dada pelos torcedores no período de maior dificuldade vivido pelo clube, onde os torcedores se mantiveram fiéis ao time com altas médias de público. Sabe-se que o clube tem alguns prejuízos nos jogos justamente por manter preços baixos demais para o seu torcedor (além de procurar promover a melhor experiência e conforto), não fazendo sentido a eles quererem barganhar por preços menores do que os já praticados.

Poder de barganha dos fornecedores - O clube possui seu próprio estádio, o que permite a ele escolher quais preços desejará adotar durante as partidas. No caso da compra de novos jogadores, o clube realiza sondagens (buscas para se saber os valores de transferência e salários dos jogadores) antes da abertura da janela de transferências permitindo mais tempo para se negociar valores com os empresários dos jogadores. Devido ao passado recente do clube, dificilmente serão comprados jogadores com valores inflacionados que façam a diretoria mudar sua política de austeridade.

Já a parceria com a patrocinadora máster do clube se iniciou ainda durante a crise financeira, em março de 2006. Naquela época, o poder de barganha do 
clube era muito baixo por causa de sua necessidade imediata em captar receita (inclusive sendo necessária a venda de seu estádio). Recentemente, a Evonik ampliou o seu contrato com o BVB até 2025 e ainda investiu cerca de $€ 26,7$ milhões para comprar $9 \%$ do total de ações do clube, se tornando sua segunda maior acionista.

O investimento está relacionado à importância do BVB para a marca nos últimos anos, devido à estabilidade financeira alcançada pelo clube e seu bom desempenho nos últimos anos. A afinidade dos alemães com a marca Evonik no início da parceria era de $47 \%$ e aumentou para $64 \%$ numa pesquisa recente do conselho químico da Alemanha. Pode-se dizer então que houve um aumento considerável do poder de barganha do clube com seu patrocinador máster, apesar da relação amigável entre as partes.

Ameaça de produtos substitutos - A torcida do BVB é totalmente apaixonada pelo clube, motivo pelo qual está sendo estudada nesta pesquisa. Além da alta identificação e fidelidade pelo clube, os torcedores são sempre estimulados por campanhas para que continuem próximos ao clube.

Além dessa forte identificação dos torcedores, muitos dos ingressos são vendidos por pacotes logo no início da temporada (os season tickets), o que dificulta bastante que o clube seja trocado por algum outro evento, já que o torcedor já pagou pelo evento e teria desperdiçado seu dinheiro não comparecendo.

Rivalidade entre os concorrentes - No âmbito nacional, o Bayern de Munique é o clube de maior torcida e força na Alemanha, mas apenas esses dois fatores não significam uma ameaça para o Borussia, a identificação com um clube nem sempre está relacionada com a questão dele ser o melhor. Conforme Morgan e Summers (2008) relatam, os consumidores esportivos são imprevisíveis e prezam pela competição.

"O que o Bayern de Munique quer dizer é que 'nós somos nós', mas eu leio como 'nós temos', querem se destacar e buscar ser algo artificialmente. $O$ 'amor verdadeiro' não é a instituição Borussia Dortmund, são as pessoas, a emoção do torcedor e a ligação dele com os jogadores, a equipe em si, não a empresa. A nossa posição em relação ao torcedor é completamente diferente do 'Mia san mia' do Bayern." (Carsten Cramer, 2014) 
Num âmbito internacional, também há outros clubes considerados mais fortes como Manchester United, Barcelona e Real Madrid, que também possuem mais torcedores que o Borussia Dortmund.

"Claro que pode existir uma competição entre os clubes, até mesmo como parâmetro para nós mesmos evoluir. Seria presunçoso pensar que poderíamos aprender com Manchester United, Real Madrid ou Barcelona em termos de internacionalização. Esses clubes tem feito bem sua parte, mas não se encaixam no que pretendemos. O BVB tem outro estilo, outros objetivos." (Carsten Cramer, 2014)

Num patamar diferente também pode-se destacar os "novos ricos", ainda que suas estruturas e a forma como conseguiram os torcedores "fiéis" sejam diferentes.

"O Fair-Play Financeiro vai tomar conta desses clubes e eles não terão vida fácil. São estruturas e quadros administrativos que não tem nada a ver com a gente, aqui se nós não queremos algo, não aprovamos. Não tem uma pessoa só que mande no clube. Apesar de tudo, eles têm sido parte da concorrência e o BVB tem que encontrar soluções criativas para responder. Mas não acho que eles consigam durar muito tempo." (Carsten Cramer, 2014)

Ainda que esses clubes tenham mais torcedores ou poder financeiro, é o Borussia Dortmund que possui a maior média de público no mundo inteiro, mostrando que suas estratégias se sobressaem no quesito de fidelizar os torcedores.

\subsection{Pesquisa com torcedores}

Foram obtidas 108 respostas entre torcedores e não torcedores de clubes de futebol através de um questionário online. O motivo de também se fazer a pesquisa com pessoas que não torcem para um time em especial ou não gostam/entendem de futebol é para ser ter uma visão mais ampla das respostas coletadas, com diferentes percepções e pontos de vista. A distribuição entre os respondentes pode ser conferida no gráfico da Figura 4: 


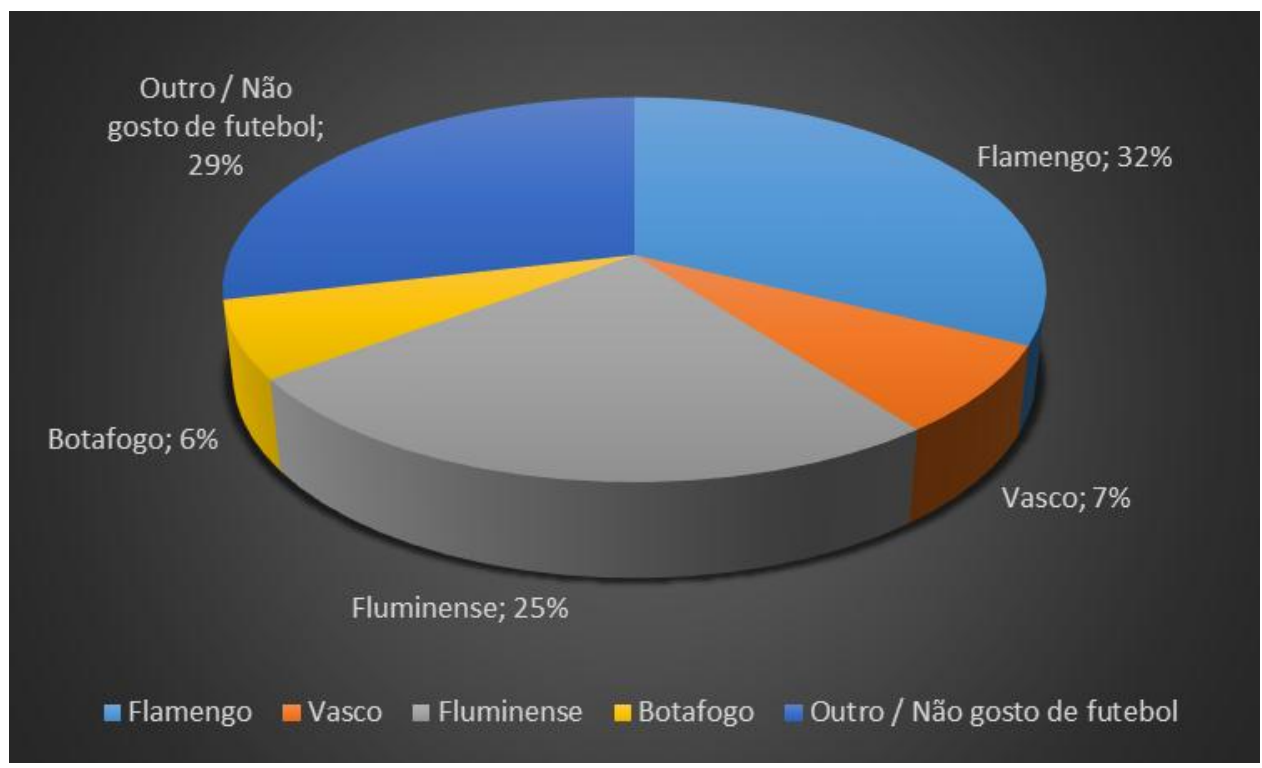

Figura 4: Qual seu time de futebol?

\subsubsection{Perfil dos torcedores}

Rein, Kotler e Shields (2008) atribuem diversos perfis para os consumidores esportivos, cada qual com diferentes atributos e comportamentos. Isso se deve à complexidade em entender o comportamento heterogêneo dos consumidores esportivos, segundo Morgan e Summers (2008).

Essa heterogeneidade de comportamentos é comprovada através do gráfico da Figura 5, onde os respondentes deveriam assinalar qual perfil definido por Rein, Kotler e Shields mais se assemelhava à sua pessoa. Com base nas diferentes respostas obtidas, percebe-se que o consumidor esportivo não pode ser compreendido como um consumidor que possa ser generalizado, necessitando um estudo mais aprofundado, como sugerem Funk, Mahony e Havitz (2003). 


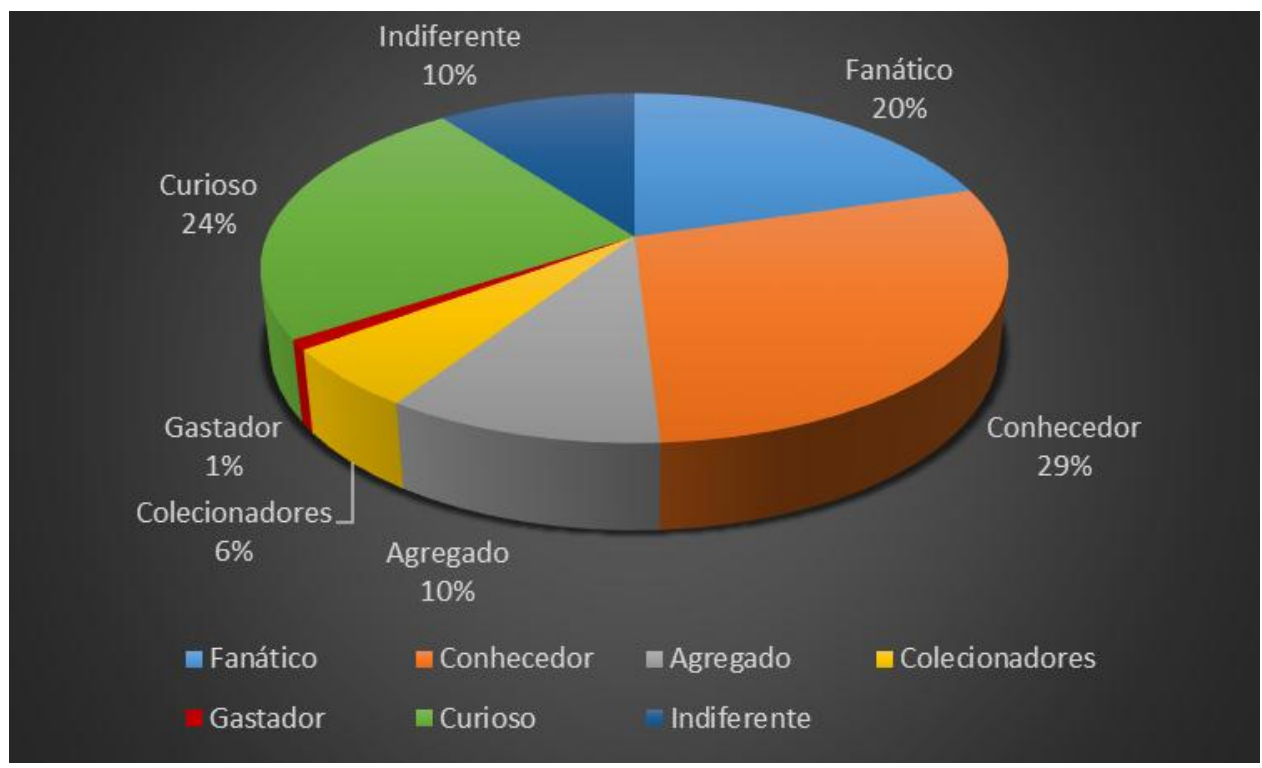

Figura 5: Perfil dos respondentes

Através da assimilação dos perfis dos respondentes, pode-se entender melhor alguns dos comportamentos e percepções pesquisadas.

Mais da metade dos Fanáticos assinalaram ir 10 ou mais vezes ao estádio em um ano (mostrando que são os que mais vezes vão ao estádio), mas também foram o grupo de respondentes que mais concordaram totalmente que o preço dos ingressos está alto. Metade dos respondentes disseram ser sócio torcedores.

Curiosos e Indiferentes são os que menos vezes vão ao estádio, apesar dos Indiferentes apresentarem uma proporção muito maior de nunca irem ao estádio que os demais. Já que não possuem ligação com futebol, nenhum dos Indiferentes respondeu ser sócio torcedor e/ou ter identificação com algum clube de futebol, diferente dos Curiosos, que responderam ter grande identificação. Apesar disso, são eles os que mais se sentem inseguros num estádio, fato que pode influenciar no baixíssimo número de sócio torcedores encontrados nesse perfil (está somente na frente dos Indiferentes).

Os Gastadores se mostraram ser torcedores que, apesar de irem poucas vezes ao estádio, são sócio torcedores de seu time e são os que mais se sentem impactados pelas ações dos clubes.

Conhecedores e Colecionadores apresentaram perfis similares, ambos são muito identificados com seus times e não se sentem inseguros em ir ao estádio, além de irem com frequência. A grande diferença entre eles é que a maioria dos Conhecedores se sentem impactados por campanhas (contra pouco menos da 
metade dos Colecionadores), enquanto que os Colecionadores são os que mais aderiram ao programa de sócio torcedor.

Por fim, os Agregados se mostraram ser os menos impactados por ações de seu clube, se sentem inseguros num estádio e pouco se identificam com os jogadores de seu time, mas possuem uma presença em estádios maior que os Curiosos.

\subsubsection{Percepção sobre o elenco}

O gráfico da Figura 6 analisa o grau de importância (sendo 1 o maior e 6, o menor) dado pelos respondentes sobre a presença de ídolos no time quando estes consideram ir a um estádio de futebol:

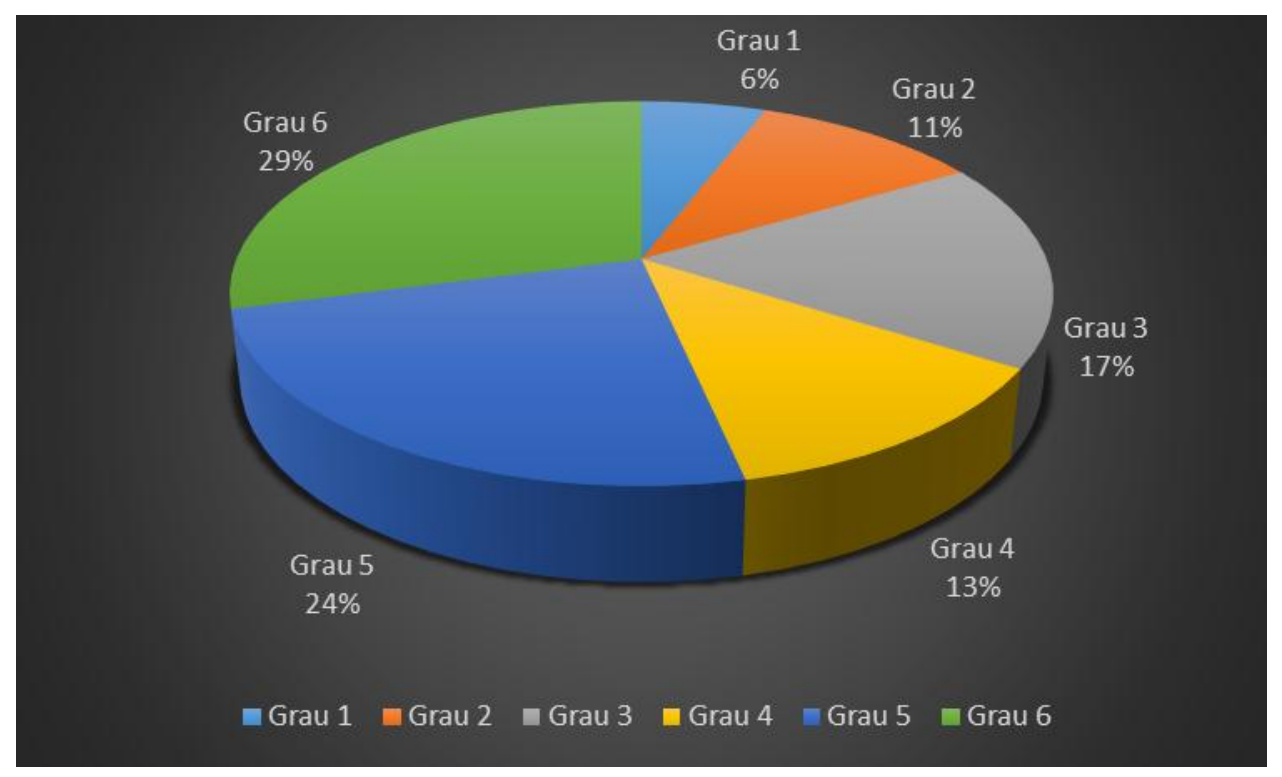

Figura 6: Grau de importância da presença de ídolos

Percebe-se pelo gráfico que mais da metade dos respondentes consideraram a presença de jogadores identificados com o clube com um grau de importância baixo. Apesar dessa baixa relevância, o grau de importância dado à situação atual do time no campeonato apresentou opiniões divergentes, com $27 \%$ dos respondentes atribuindo o grau mais importante para esse quesito em contraste à $20 \%$ atribuindo um grau médio-baixo. 


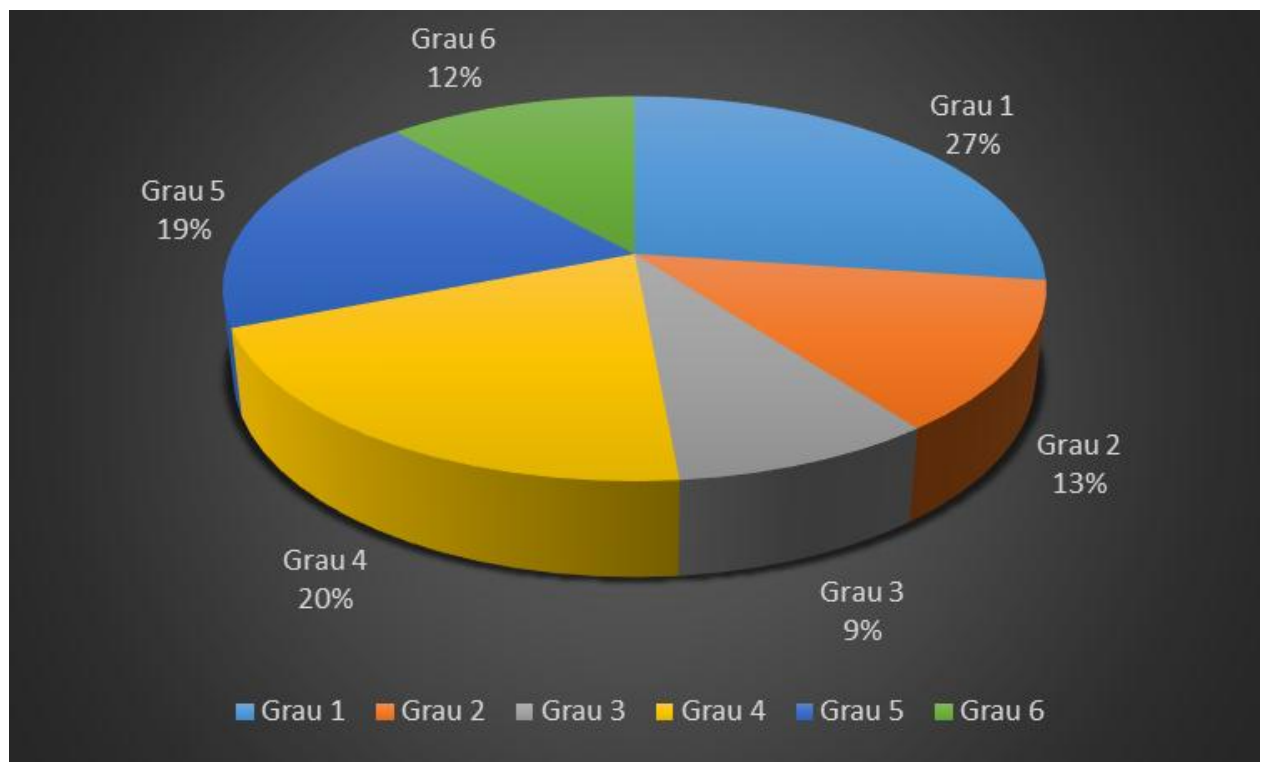

Figura 7: Grau de importância da situação do time no campeonato

\subsubsection{Percepção sobre o conforto}

\subsubsection{Segurança}

O gráfico da Figura 8 analisa o grau de importância (sendo 1 o maior e 6, o menor) dado pelos respondentes à segurança quando estes consideram ir a um estádio de futebol:

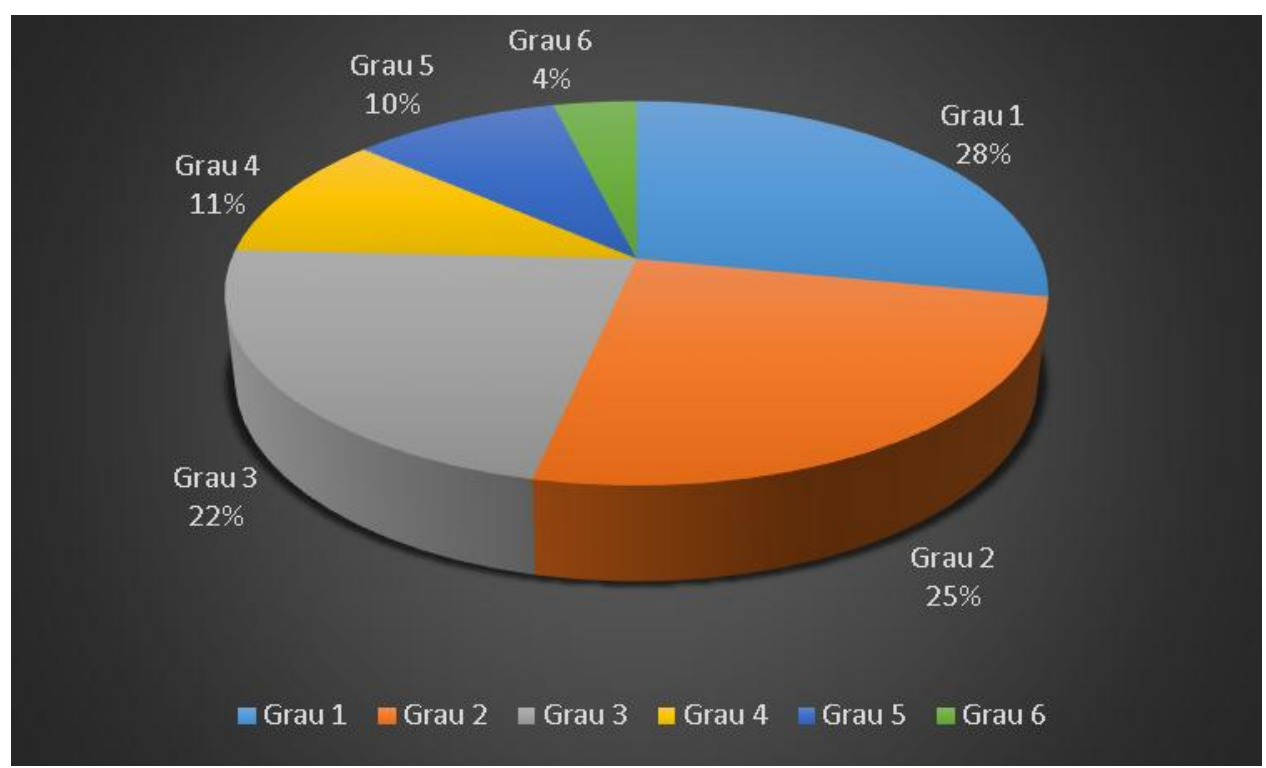

Figura 8: Grau de importância da segurança 
Percebe-se por esse gráfico que a maioria dos respondentes consideraram a segurança como um fator muito importante ao decidir frequentar um estádio. Para se verificar este assunto de forma mais aprofundada, foi feita uma tabulação cruzada entre a concordância/discordância para a afirmação "Me sinto seguro num estádio de futebol" e a frequência que os respondentes vão aos estádios.

\section{Tabela 5: Segurança x Frequência nos estádios}

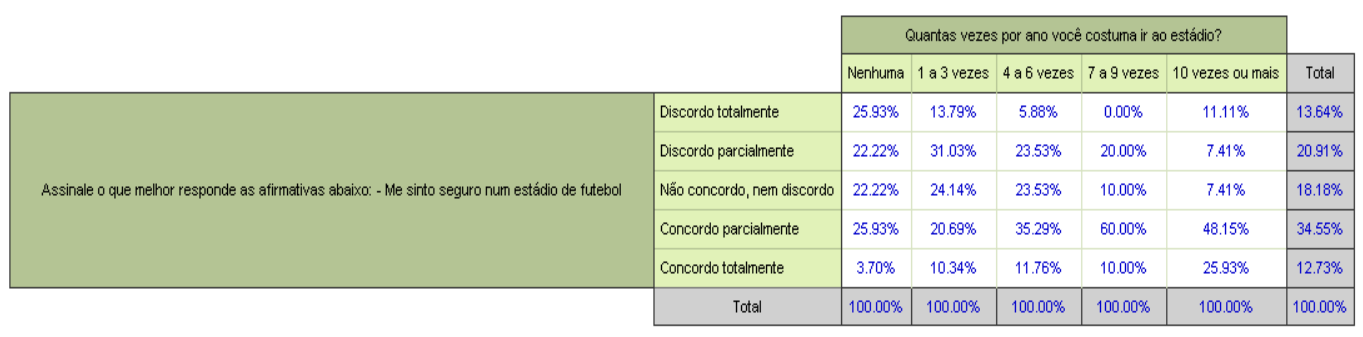

A Tabela 5 revela diferentes percepções dos respondentes para a afirmação. Os respondentes que apresentaram o maior percentual de total discordância são justamente aqueles que responderam não ter o costume de ir aos estádios, o que pode representar que essas pessoas evitam frequentar um estádio por terem uma imagem de insegurança e/ou violência do lugar. Indo no sentido contrário, a maioria dos respondentes que mostraram ter concordância em enxergar um ambiente seguro num estádio são os maiores frequentadores do lugar, porém, percebe-se pelos dados da tabela que ainda há um consenso entre os respondentes de que um estádio de futebol no Brasil ainda não é de uma forma geral, totalmente seguro.

\subsubsection{Acesso}

O gráfico da Figura 9 abaixo analisa o grau de importância (sendo 10 maior e 6, o menor) dado pelos respondentes à facilidade do acesso quando estes consideram ir a um estádio de futebol: 


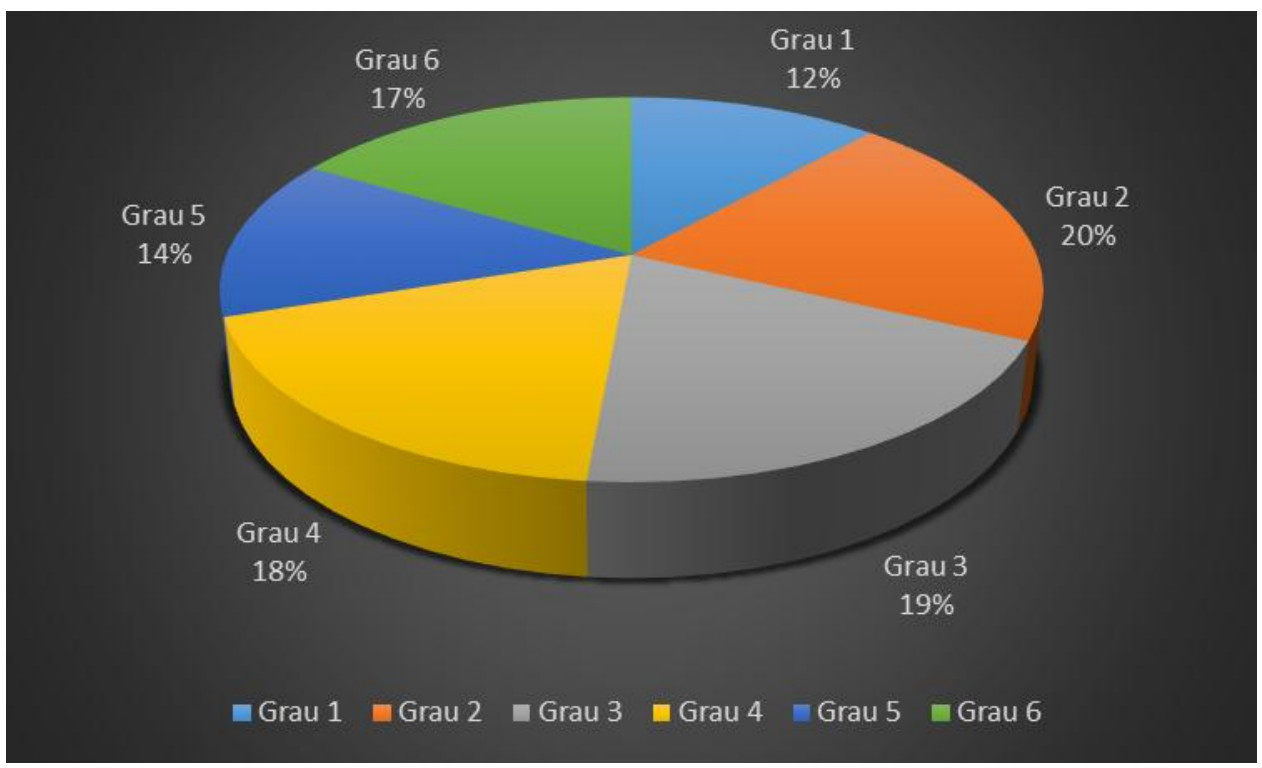

Figura 9: Grau de importância do acesso

Apesar de todos os quatro clubes cariocas compartilharem o uso do Maracanã, apenas Vasco e Botafogo possuem um estádio próprio (São Januário e Engenhão, respectivamente) para atuar como mandante contra times de outros estados sem a necessidade de um aluguel. Dessa forma, foi feita uma tabulação cruzada entre a concordância/discordância para a afirmação "O estádio do meu time é de fácil acesso" e o time do respondente, para se entender melhor a percepção de cada um dos torcedores quando estes se locomovem para o estádio de seu time.

\section{Tabela 6: Acessibilidade x Time}

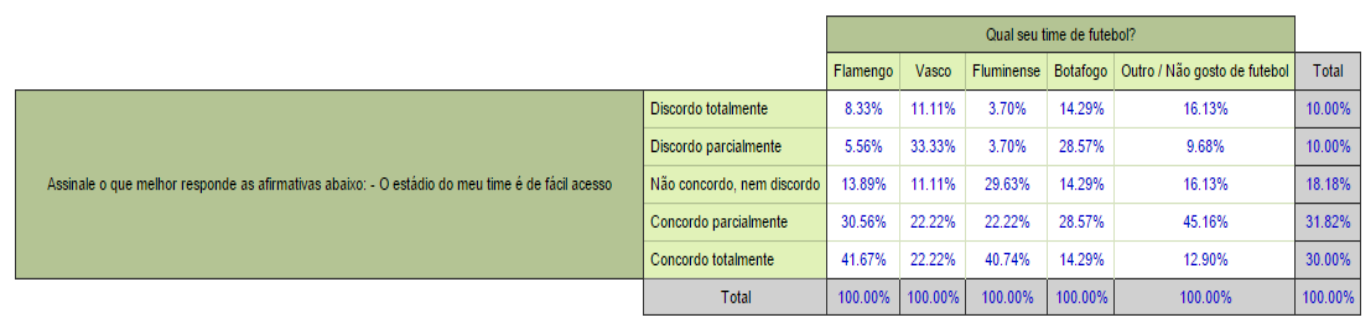

De uma forma geral, a representatividade de respondentes que têm dificuldades para acessar o estádio de seus times se mostrou ser muito baixa, com apenas $20 \%$ de discordantes da afirmação, sejam eles de forma parcial ou total. Por outro lado, cerca de $62 \%$ dos respondentes afirmaram que não têm grandes dificuldades para acessar o estádio. 
Apesar da questão de acessibilidade do estádio depender mais do governo do que dos clubes na maioria dos casos, o torcedor do Borussia Dortmund também é privilegiado neste quesito. Somente no dia dos jogos do Borussia, uma estação de metrô sob o estádio, servida de duas linhas, é aberta para os torcedores chegarem ao Signal Iduna Park. Esse é mais um exemplo de que o clube não vê seu torcedor como apenas um recurso financeiro, não medindo esforços para sempre promover a melhor experiência possível a ele. Analisando essa questão de uma forma mais profunda, todos os times da 1ㅁำ divisão alemã (sem qualquer exceção) são acessíveis por trem, mas essa já seria uma questão para a CBF (Confederação Brasileira de Futebol, o órgão que gere o futebol no Brasil) e o governo brasileiro.

Em se tratando dos grupos de torcedores questionados, percebe-se que os torcedores de Botafogo e Vasco apresentaram uma discordância muito maior à afirmação de acessibilidade ao seu estádio do que Flamengo e Fluminense, que demonstraram ter percepções similares (o que é compreensível uma vez que os torcedores frequentam o mesmo estádio). Se comparado ao Signal Iduna Park, o Estádio de São Januário e o Engenhão não possuem uma linha própria de metrô que deixem os torcedores a poucos minutos da entrada do estádio. Para acessar o Engenhão, uma pessoa pode acessar um ônibus ou o metrô como transporte público, mas ainda será necessária caminhar alguns minutos até o estádio. Para acessar o Estádio de São Januário, apenas o ônibus está à disposição como transporte público para quem quiser acessá-lo. No caso do Maracanã, os torcedores têm acesso aos ônibus e metrô, assim como o Engenhão, mas a grande diferença é que a estação mais próxima ao estádio deixará o visitante a alguns passos da entrada, que poderá ser realizada sem muitos problemas.

Ter um estádio próprio é fundamental para qualquer estratégia de um clube de futebol (uma delas sendo o preço dos ingressos, que já foi percebido nesta pesquisa como um ponto muito importante), mas é necessário que se dê a devida atenção ao conforto do torcedor para que se possa tirar o máximo proveito deste recurso chave.

\subsubsection{Percepção sobre o preço dos ingressos}

O gráfico da Figura 10 abaixo analisa o grau de importância (sendo 10 maior e 6, o menor) dado pelos respondentes ao preço dos ingressos quando estes consideram ir a um estádio de futebol: 


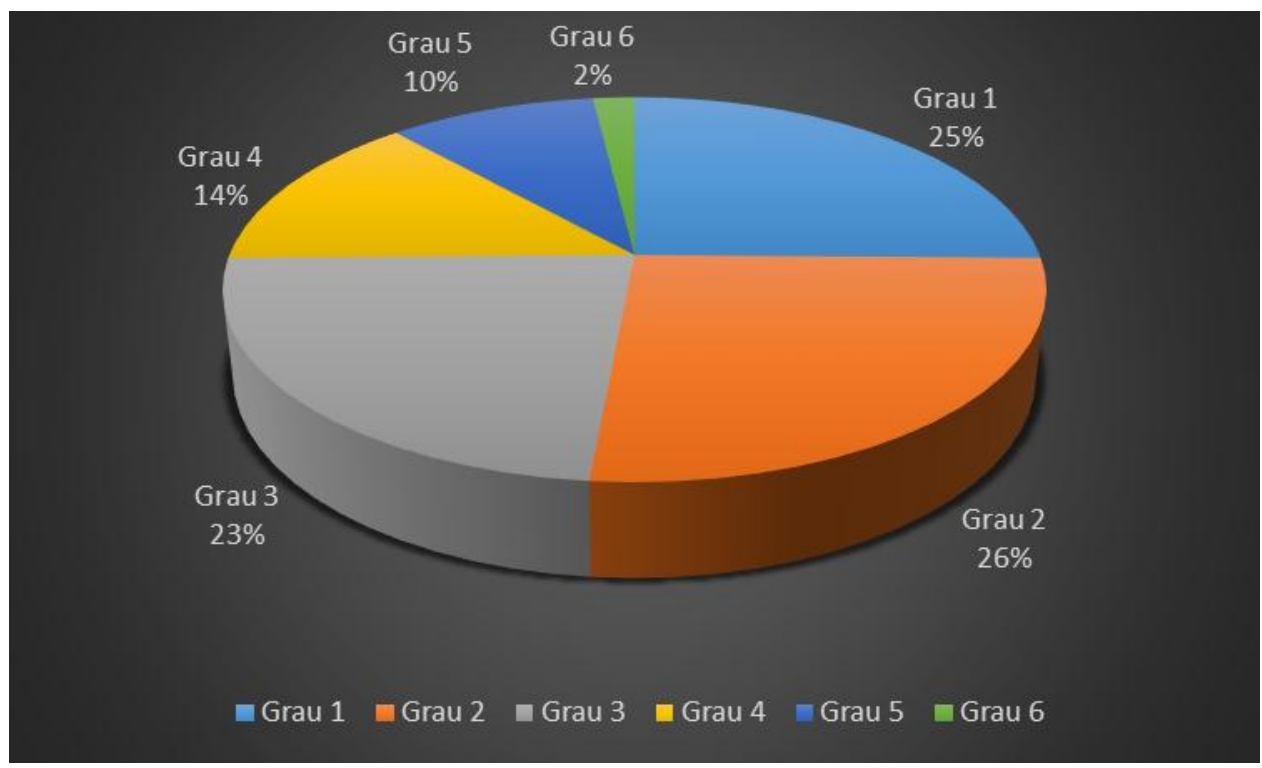

Figura 10: Grau de importância do preço dos ingressos

Percebe-se pelo gráfico que mais da metade dos respondentes consideraram o preço do ingresso com um alto grau de importância. Para reforçar a relevância deste assunto, foi feita uma tabulação cruzada entre a concordância/discordância para a afirmação "O preço cobrado pelos ingressos é alto" e a frequência que os respondentes vão aos estádios.

Tabela 7: Preço do ingresso x Frequência nos estádios

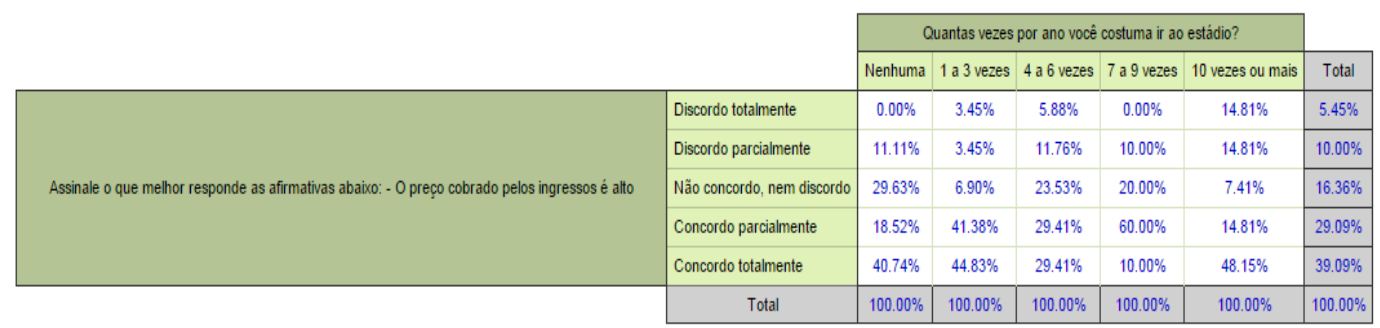

A Tabela 7 não só comprova o que é apresentado no Gráfico 3, como também revela uma percepção do torcedor brasileiro. Quase que de forma unânime, os respondentes apresentaram uma concordância ao menos parcial de que os preços praticados no Brasil na venda de ingressos para os jogos de futebol são de alto valor, inclusive para os torcedores que responderam que comparecem aos estádios com uma frequência muito alta.

Segundo um levantamento do jornal inglês Daily Mail (2014), o Brasil possui o segundo ingresso mais caro do mundo (proporcionalmente à renda per capita da população), sendo superado apenas pela China. O preço médio para 
um jogo do Brasileirão é de $£ 12,73$ libras (cerca de $R \$ 52,00$ ), e se for levado em consideração a renda per capita de uma semana, um brasileiro poderia comprar 14,2 ingressos.

Se for comparado ao terceiro campeonato mais caro do mundo, a Premier League da Inglaterra, o preço médio do ingresso é elevado para $£ 28,80$ (cerca de $R \$ 117,00)$. O preço do ingresso na Inglaterra é justificado pelo fato dos ingleses possuírem uma renda per capita semanal maior (o que lhes permitem comprar 14,3 ingressos em uma semana) e uma fortíssima demanda, já que é o segundo campeonato que mais atrai torcedores aos estádios (como pode ser conferido na Tabela 1).

O que torna este cenário lamentável para os brasileiros é que, dos 5 ingressos mais caros do mundo (Turquia e Espanha completam o Top 5 como quarto e quinto, respectivamente), o campeonato realizado no Brasil é o que está em pior colocação em termos de demanda, na 15a posição. Se levados em consideração os resultados encontrados nos Gráficos 3 e 4 acima, pode-se interpretar que esta $15^{\underline{a}}$ posição muito se deve ao preço praticado pelos clubes brasileiros. Uma sugestão aos clubes analisados é a de considerar a renda per capita do Brasil e o aporte financeiro de seus torcedores, procurando dessa forma praticar um preço que atenda a expectativa de seus consumidores, atraindo mais torcedores para os estádios e possivelmente facilitando uma aproximação deles às ações estratégicas que o clube em questão pense em implementar.

"No Brasil, os clubes elevam os preços porque tentam passar para o consumidor o custo de um futebol inflacionado por salários irreais. É preciso pensar em escala: estádios cheios a um preço unitário de ingresso um pouco menor tendem a produzir arrecadação total maior. Além disso, geram outras oportunidades de receita. " (Ferreira, 2015)

Prezar pelo bem-estar e respeitar seus torcedores são duas grandes virtudes do Borussia Dortmund, que apesar de todas as mudanças ocorridas durante os tempos de crise, jamais deixou de ter um setor popular no Westfalenstadion e jamais abriu mão de sua torcida.

"[...] A proximidade com a torcida é um dos nossos trunfos, baseamos muitas decisões nas opiniões deles, e isso nos impede de cometer alguns erros, ou afastar o clube da sua essência."

[Perguntado sobre quais erros seriam esses] "Erros como não ser acessíveis ou se tornar uma sociedade fechada. A política de preços é um exemplo claro, onde nosso estádio é o que tem mais lugares em pé [ingressos populares] da Europa. 
Nosso material esportivo nas lojas físicas é mais barato do que dos rivais, e a alimentação no estádio está totalmente dentro do que o torcedor pode consumir. A cerveja custa só $€ 3,70$, não tem como deixar o torcedor mais contente! [...]" (Carsten Cramer, 2014)

Segundo os números do site do Borussia Dortmund (2014/2015), os ingressos para o Signal Iduna Park nesta temporada custam entre $€ 6,50$ e $€$ 52,00 , quando comprados individualmente. No começo da temporada, o torcedor ainda pode optar por comprar um carnê com todos os ingressos dos 17 jogos em casa da Bundesliga (preços entre € 4,50 e € 41,50 por jogo), ou então um carnê com estas mesmas 17 partidas e mais as outras três da fase de grupos da Champions League (preços entre $€$ 4,60 e $€ 43,00$ por partida).

Essa estratégia (adotada pelos clubes da Alemanha) de adotar um season ticket garante ao clube um torcedor fiel, que vai a todas as partidas. Como o ingresso já foi comprado para toda a temporada, ele irá à partida de qualquer forma. No Brasil, quando o clube vai mal, o torcedor costuma comparecer num número menor.

Segundo contas da diretoria do clube, eles deixam de ganhar cerca de 4,5 milhões de euros por ano por continuarem a vender ingressos baratos, mas não abrem mão da torcida que não largou o time nem nos piores momentos. No auge da crise, a média de público jamais foi menor do que 70 mil torcedores.

"[...] E é disso que falo em relação ao 'amor verdadeiro', não se trata de uma campanha com um slogan vazio, mas algo com o que nos preocupamos e levamos a sério." (Carsten Cramer, 2014)

\subsubsection{Percepção sobre as campanhas aos torcedores}

O Gráfico abaixo analisa o grau de importância (sendo 1 o maior e 6, o menor) dado pelos respondentes às campanhas direcionadas a eles quando consideram ir a um estádio de futebol: 


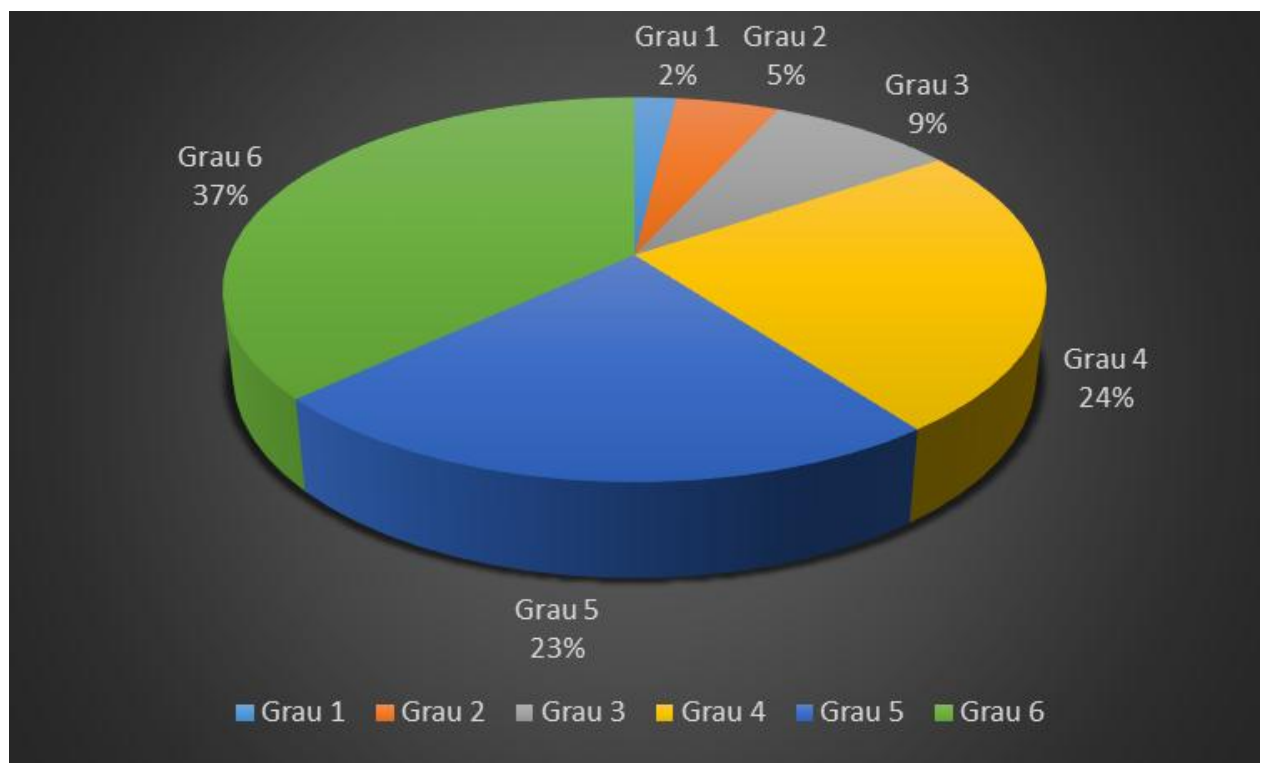

Figura 11: Grau de importância das campanhas para os torcedores

Percebe-se pelo gráfico da Figura 11 que, quase que de forma unânime, os respondentes não consideram as campanhas que seu clube promove a eles como um fator decisivo para que ele vá acompanhar o seu time no estádio.

Para aprofundar este assunto, foi feita uma tabulação cruzada entre a concordância/discordância para a afirmação "Sou impactado pelas campanhas do meu time" e se os respondentes são sócio torcedores de seus times. Também foi verificada a proporção entre sócios e não sócios por cada time analisado.

Tabela 8: Campanha para torcedores x Sócio Torcedor

\begin{tabular}{|c|c|c|c|c|}
\hline & & \multirow{2}{*}{\multicolumn{2}{|c|}{ Vocese só socio torcedor do seu time? }} & \multirow{3}{*}{ Total } \\
\hline & & & & \\
\hline & & Sim & Năo & \\
\hline \multirow{6}{*}{$\begin{array}{l}\text { Assinale o que menhor responde as affrmativas abbivio: Sou impactiado pelas canpanhas do meu } \\
\text { time }\end{array}$} & Discordo totalmente & $6.67 \%$ & $19.23 \%$ & $15.74 \%$ \\
\hline & Discordo parcialmente & $13.33 \%$ & $12.82 \%$ & $12.96 \%$ \\
\hline & Näo concordo, nem discordo & $16.67 \%$ & $24.36 \%$ & $22.22 \%$ \\
\hline & Concordo parcialmente & $40.00 \%$ & $26.92 \%$ & $30.56 \%$ \\
\hline & Concordo totalmente & $23.33 \%$ & $16.67 \%$ & $18.52 \%$ \\
\hline & Total & $100.00 \%$ & $100.00 \%$ & $100.00 \%$ \\
\hline
\end{tabular}

A Tabela 8 revela um dado interessante: cerca de $44 \%$ dos respondentes que revelaram não ser sócio torcedores afirmaram se sentir impactados pelas campanhas de seus times (sendo que cerca de 17\% afirmaram se sentir totalmente impactados). Isso significa que, mesmo se as campanhas estejam 
sendo bem executadas, elas não estão obtendo êxito no seu objetivo de trazer os torcedores para mais próximo do clube e aderir ao programa de sócio torcedor.

Por outro lado, $20 \%$ dos respondentes que revelaram ser sócios afirmaram não se sentir impactados pelas ações de seu time. É possível que esses respondentes sejam de outros estados e contribuem com o programa de sócio torcedor sem pensar nos benefícios disponíveis, mas sim em ajudar o seu time. Mesmo que seja natural as ações do time serem concentradas para a área onde ele atua, mapear a concentração de torcedores fora dessa área e planejar ações com eles poderia uma boa estratégia para trazer novos sócios e aumentar o apoio ao time em jogos fora de seu território.

\section{Tabela 9: Sócio Torcedor x Time}

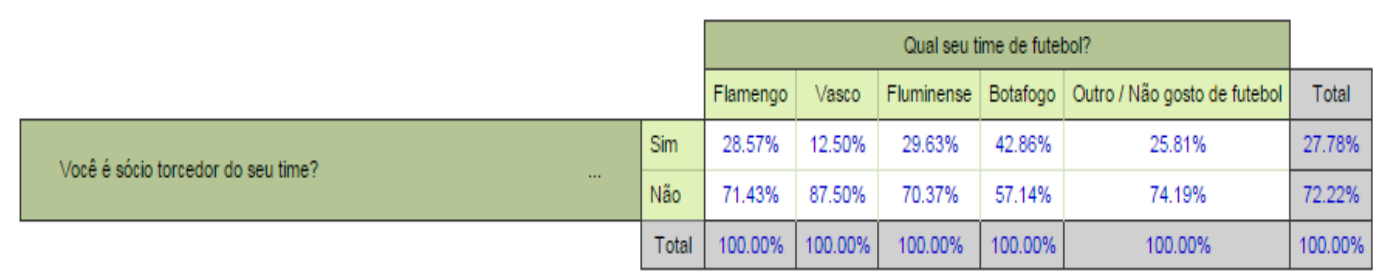

Na Tabela 9, percebe-se que o número de torcedores que não são sócio torcedores é muito maior dos que aqueles que aderiram ao programa de seus times, com somente o Botafogo mantendo uma porcentagem mais equilibrada (mas ainda assim, apresentando um número maior de não sócios). Quando um torcedor decide ser sócio torcedor, por qualquer motivo que seja, o senso comum é de que ao menos esse torcedor se sente identificado com seu time ao ponto dele querer contribuir com o seu crescimento. Nesse pensamento, um perfil de torcedor "Indiferente", como perfilado por Rein, Kotler e Shields (2008), dificilmente poderia ser um sócio torcedor por não ter um interesse no esporte, e consequentemente, identificação com algum time.

Ter uma equipe forte e competitiva pode ser um grande atrativo para novas adesões de sócios, entretanto, campanhas e ações voltadas para os torcedores também são bons meios de atraí-los. Deve-se levar em consideração a afirmação de Funk, Mahony e Havitz (2003), que se deve evitar generalizar o consumidor esportivo, um dos possíveis motivos para isso (e que pode ser considerado para este caso específico) é que a "essência do que querem pode ser um mistério", segundo Morgan e Summers (2008). Em outras palavras, não 
quer dizer que uma campanha terá o mesmo impacto em torcedores de diferentes times.

Apesar de ter uma equipe considerada forte no campeonato local, o Borussia Dortmund chegou a ocupar as últimas colocações do campeonato durante a parada de inverno de 2014. Como uma forma de se reconciliar com a torcida, o clube realizou uma ação neste período de folga: colocou os jogadores em um bar servindo cerveja. O evento aconteceu na festa de Natal anual realizada junto aos fã clubes do Borussia. Cerca de mil pessoas foram ao Signal Iduna Park para tomar cervejas servidas por Marco Reus, Roman Weidenfeller, Mats Hümmels e outros destaques do time. Outra ação de destaque realizada pelo clube nesse período se deu no hospital infantil da cidade, onde parte do elenco distribuiu presentes para os pequenos fãs aurinegros.

Essas duas campanhas são dois bons exemplos de como o clube sempre busca estar próximo de seu torcedor, mesmo que não seja na melhor fase do time. Do ponto de vista estratégico, aproximar os jogadores aos torcedores pode ser benéfico para a performance dos jogadores, já que a união com aqueles que tanto os apoiam pode gerar uma dedicação maior dos jogadores durante os jogos.

O Borussia também possui um grande parceiro de campanha para torcedores em seu patrocinador master. Em partidas importantes do Borussia Dortmund como visitante, a Evonik banca as passagens de trem para os torcedores. Na final da Copa da Alemanha de 2012, por exemplo, a empresa levou cerca de sete mil torcedores para Berlin. Aqueles que não tinham ingresso puderam ver o jogo contra o Bayern de Munique em um telão montado pela patrocinadora na capital.

Para todos os jogos do clube, o clube e a Evonik trabalham no sentido de produzir um anúncio específico para aquela ocasião. Para cada partida, uma peça publicitária diferente. O sucesso foi tanto entre o público que esses anúncios passaram a ser estudados por profissionais e estudantes de marketing na Alemanha.

É justamente por esses exemplos de estratégias de campanhas que os torcedores criam uma afinidade tão grande com o time que a fase já não importa tanto. Pouco depois de retornarem da parada de inverno mencionada, o Borussia chegou à lanterna (última colocação) do campeonato após um empate e uma derrota (essa, em casa) e necessitava ao máximo de sua torcida, que correspondeu. 
Apesar de receber muitas cobranças após a derrota em casa no Signal Iduna Park, o Borussia recebeu 653 novos sócios na semana seguinte, 30\% a mais que a média de 500. Seja por apoio ao time ou pelo "vínculo emocional" entre torcida e time, o Dortmund terminou o mês de fevereiro com 116.792 sócios, em terceiro lugar no ranking desse quesito na Alemanha, atrás apenas do Schalke 04 (135 mil) e Bayern de Munique (251 mil).

\subsection{Pesquisa com um gestor de futebol}

Além da pesquisa com os 108 torcedores, foi realizada uma entrevista em profundidade com Daniel Pereira Jr, que foi Diretor de Futebol no Botafogo. A partir das respostas coletadas, pode-se conhecer um pouco mais sobre a realidade de um clube brasileiro e fazer algumas comparações com o Borussia Dortmund.

O Botafogo é um clube de grande tradição no futebol brasileiro e já formou verdadeiros esquadrões no seu passado, que contava com craques como Garrincha, Nilton Santos e Gerson "Canhotinha de Ouro". Apesar do seu passado como um dos principais clubes do Brasil (além de manter até hoje a marca de clube que mais cedeu jogadores para a seleção brasileira), a realidade do clube hoje em dia é bem diferente: foi rebaixado para a segunda divisão nacional após um ano repleto de penhoras e dívidas contraídas por administrações falhas, que estavam sendo repassadas de gestão para gestão sem que houvesse uma ação prioritária em saná-las, ao ponto de se tornarem os piores problemas do clube atualmente.

"No momento atual, com os órgãos de governo exercendo o seu dever de fiscalização, os clubes descobriram que precisam tratar deste problema, mas não estão preparados, daí toda a dificuldade. O regime presidencialista, com órgãos de controle interno políticos, comprometidos e fracos, facilitam e permitem um endividamento do clube além das suas possibilidades." (Daniel Pereira Jr, 2015)

Suas maiores fontes de receitas se dão através dos contratos firmados para a transmissão na TV, patrocínios na camisa, material esportivo, produtos licenciados, bilheteria em seu estádio (o Engenhão) e a formação de atletas oriundos da base, que vem crescendo ao longo dos anos como uma fonte de receita para o clube. O programa de sócio torcedor não foi citado na entrevista como uma das principais fontes de receita do clube, sendo apontado como um produto de grande potencial mas que ainda necessita de uma atenção maior. 
$\mathrm{Na}$ captação dos recursos necessários para o seu funcionamento, o clube faz uso do contrato firmado com seus fornecedores, mantendo uma relação profissional entre as partes. A forma como a gerência comercial atua no clube é fundamental para trazer novos clientes e há também empresas no mercado que atuam como facilitadoras das negociações.

Segundo Daniel, "o torcedor gosta de ver o jogador formado no clube vestindo a camisa, a torcida pelo surgimento de craque é sempre muito grande e atrai o torcedor.", e o clube parece demonstrar seguir essa ideologia. Apesar de não haver uma maneira específica da equipe jogar entre os seguimentos de futebol do clube, há um trabalho em conjunto com a comissão técnica para que o elenco tenha três jogadores por posição no elenco, sendo que sempre deverá haver ao menos um jogador vindo da base do clube entre esses três, como uma forma de dar experiência e oportunidades para o surgimento de novos valores. Para obtenção de jogadores, foram citados que o técnico, a base, olheiros e inclusive os empresários são fundamentais para esse processo.

Em se tratando do conforto dado aos torcedores, há uma percepção de que ainda é preciso evoluir, apesar de já serem mais confortáveis e seguros do que no passado. O transporte e estacionamento no entorno dos estádios foram apontados como problemas que ainda necessitam ser melhorados, além dos horários inadequados de alguns jogos. Indo de acordo com o pensamento dos torcedores, o preço do ingresso foi apontado como alto e que deve ser adequado com a qualidade do evento.

Por fim, o clube possui um planejamento estratégico, mas está pautado nos resultados obtidos em campo, o que pode acabar atrapalhando o clube num momento ruim do time. Além disso, o clube ainda trabalha de forma tímida com algumas iniciativas em alguns jogos, que se baseiam principalmente no envolvimento dos jogadores com os torcedores.

\subsection{Análise das pesquisas}

Através de uma análise das médias obtidas entre as respostas dadas na questão que busca entender o grau de importância dos fatores motivacionais à ida ao estádio, pôde-se chegar à conclusão de que as pessoas enxergam o seu bem-estar e o preço do evento como os mais importantes fatores a serem levados em consideração quando se sujeitam a ir a um estádio de futebol. 
A Figura 12 retrata a ordem crescente da importância atribuída aos itens perceptivos na visão dos respondentes. Vale ressaltar que foi atribuído ao Grau 1 o grau de maior importância e ao Grau 6, o de menor.

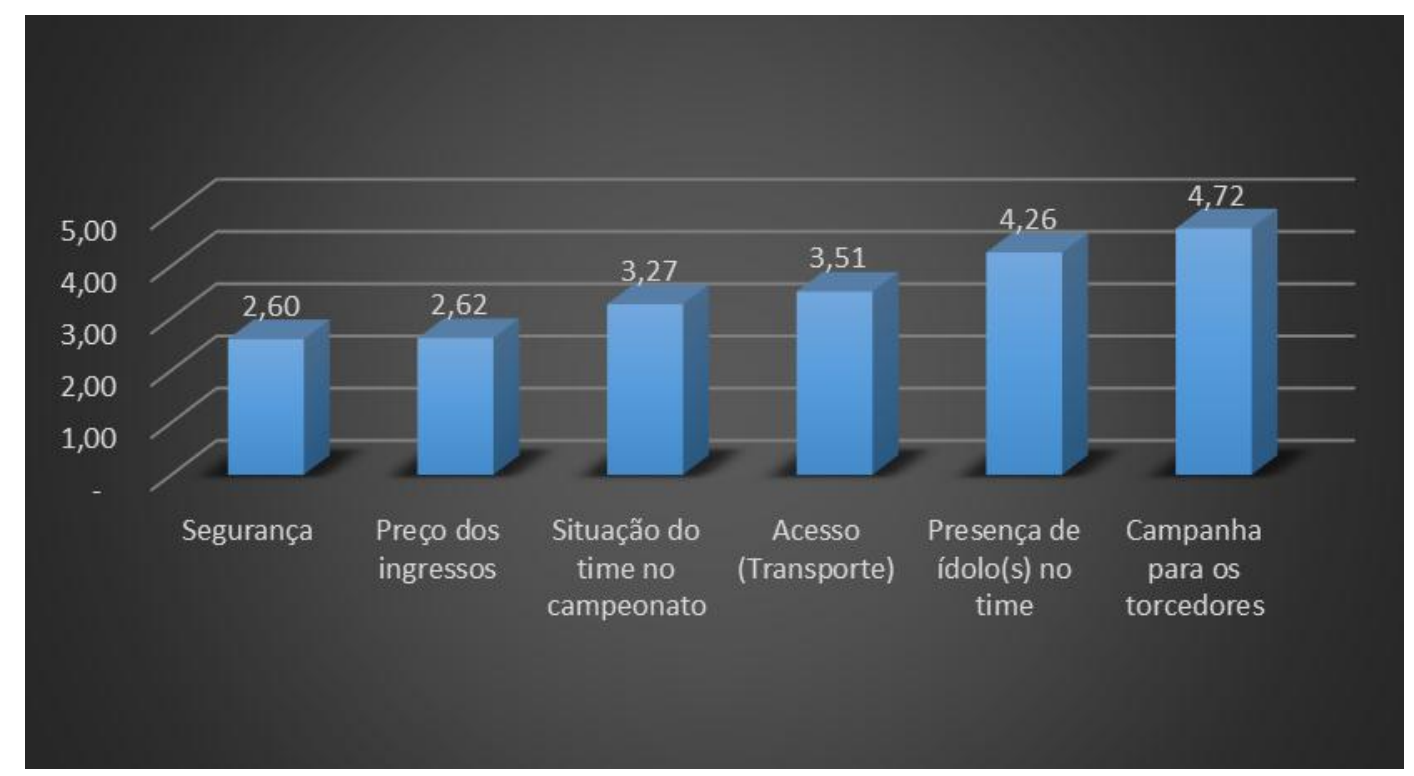

Figura 12: Visão geral da importância dos itens analisados

Ao se verificar os resultados de cada time, percebeu-se certa homogeneidade em algumas respostas entre os torcedores, como a percepção unânime entre os torcedores dos quatro times analisados de que o valor cobrado pelo ingresso não corresponde com o evento em questão. E esse pode ser um dos grandes fatores que afastam os torcedores brasileiros dos estádios.

Segundo um estudo acadêmico feito por Rodolfo Ribeiro (professor de administração e marketing e líder do núcleo de pesquisas em futebol do Senac em São Paulo) citado por Rodrigo Capelo em seu blog Dinheiro em Jogo (2015), um clube de futebol brasileiro poderia arrecadar 0 dobro do que fatura atualmente se os estádios fossem absolutamente seguros.

Deve-se imaginar o seguinte contexto para entender o estudo: um time irá enfrentar seu principal adversário, clássico, na final da Copa Sul-Americana (esta competição foi escolhida no lugar da Copa Libertadores - o maior torneio entre clubes sul-americanos - porque o pesquisador supôs que o torcedor está disposto a assumir mais riscos para ir à partida final da Libertadores) $O$ ingresso custa $R \$ 100$. Com a atual segurança nos estádios, a probabilidade do torcedor deste time comprar a entrada é de $44,5 \%$. O estádio vai lotar, porque o apelo da ocasião é muito alto, mas não quer dizer que todo o potencial de receita foi atingido. 
Porém, se nesse mesmo contexto for considerado que a segurança esteja garantida (com policiais na região, acesso facilitado e harmonia entre torcidas), a probabilidade de compra da entrada sobe para $67,3 \%$. O estádio tem o mesmo tamanho e irá lotar com uma facilidade maior, permitindo ao clube de cobrar mais caro pelo ingresso: $\mathrm{R} \$ 209$, pouco mais que o dobro do que no contexto da segurança atual.

"A probabilidade de compra de um ingresso nunca chega a 100\%, porque há pessoas que não se interessam por ele. Não importa o preço que você coloque numa manteiga, por exemplo, há pessoas que não se interessam pelo produto mesmo que ele esteja barato. Mas à medida que o preço se altera a probabilidade de compra aumenta e gera crescimento na demanda" (Rodolfo Ribeiro, 2015)

De acordo com Capelo, o estudo foi feito em duas etapas. "Na primeira, a coleta dos dados, 187 pessoas responderam questionários online que simulavam a escolha por um ingresso. Para cada jogo, mudavam preço, adversário e horário da partida. Havia duas opções: comprar ou não comprar. Cada indivíduo pôde escolher quantos jogos quisesse, inclusive nenhum. Entre essas pessoas, havia $80,2 \%$ de homens e $19,8 \%$ de mulheres, e idades variaram entre 16 e 87 anos, com média de 29,7 anos."

$\mathrm{Na}$ segunda etapa, a análise dos dados, Ribeiro usou modelagem estatística conhecida como regressão logística para calcular a intenção de compra do torcedor conforme cada variável. Segundo Ribeiro, a confiabilidade do resultado na hipótese citada, a "margem de erro", é de 95\%.

Apesar da arrecadação adicional que os clubes teriam com uma segurança assegurada poder variar devido às variáveis que dizem respeito ao tamanho da torcida e ao tamanho do estádio (que não foram consideradas no estudo), o estudo apresenta um notável parâmetro que permite medir o quanto se perde devido à negligência do poder público e dos próprios clubes em tratarem de assegurar a segurança e conforto aos seus torcedores nos estádios.

Em se tratando do Borussia Dortmund, o clube alemão demonstrou que ações simples e rápidas podem ser tomadas a fim de combater atos de intolerância nos estádios. Em uma partida contra o Hamburg, no Imtech Arena da cidade de Hamburgo, um torcedor aurinegro realizou uma saudação nazista durante uma homenagem ao falecido fisioterapeuta do time de Hamburgo.

Antes mesmo de qualquer decisão tomada pelas autoridades alemãs, o Borussia tratou de sancionar sua própria punição a esse torcedor. Em seu site oficial, o clube alemão publicou que o torcedor (cujo nome foi preservado) estava 
proibido de frequentar qualquer estádio alemão pelos próximos três anos e só poderá frequentar o Signal Iduna Park a partir de 2020. No comunicado, o clube afirma "ter uma conviç̧ão para que exista tolerância e diversidade e se vira contra qualquer forma de racismo e discriminação".

A cidade de Dortmund tem uma das maiores cenas de extrema-direita e neonazistas na Alemanha, mas para buscar causar uma reflexão entre os torcedores mais extremistas (e que podem eventualmente acabar manchando a imagem do clube), lançou-se uma campanha: foram distribuídos nos bares de toda a cidade um milhão de porta-copos com o símbolo do time e a frase "sem cerveja para racistas".

Segundo o presidente do clube, Reinhard Rauball "O Borussia Dortmund, o departamento de fãs e todos os torcedores do BVB têm a responsabilidade de se posicionar contra slogans xenófobos e desumanos, ao invés de não escutálos. Por um BVB colorido e tolerante"

Exemplos como esses mostram que um clube pode sim tomar as devidas medidas para tornar o estádio de futebol agradável para os torcedores comuns e simpatizantes, aqueles que vão para realmente assistir ao espetáculo. As autoridades têm sua parcela de responsabilidade na resolução do problema, mas isso não impediu que o clube alemão tomasse a responsabilidade para si e resolvesse o problema, e tampouco um clube brasileiro precise esperar alguma posição das autoridades locais para tomar uma atitude.

A Tabela 10 retrata o comparativo da percepção entre o grupo de torcedores analisados. Vale lembrar que não foi feita uma referência ao quesito do acesso ao estádio por já ter sido comentado anteriormente.

\section{Tabela 10: Percepção por time}

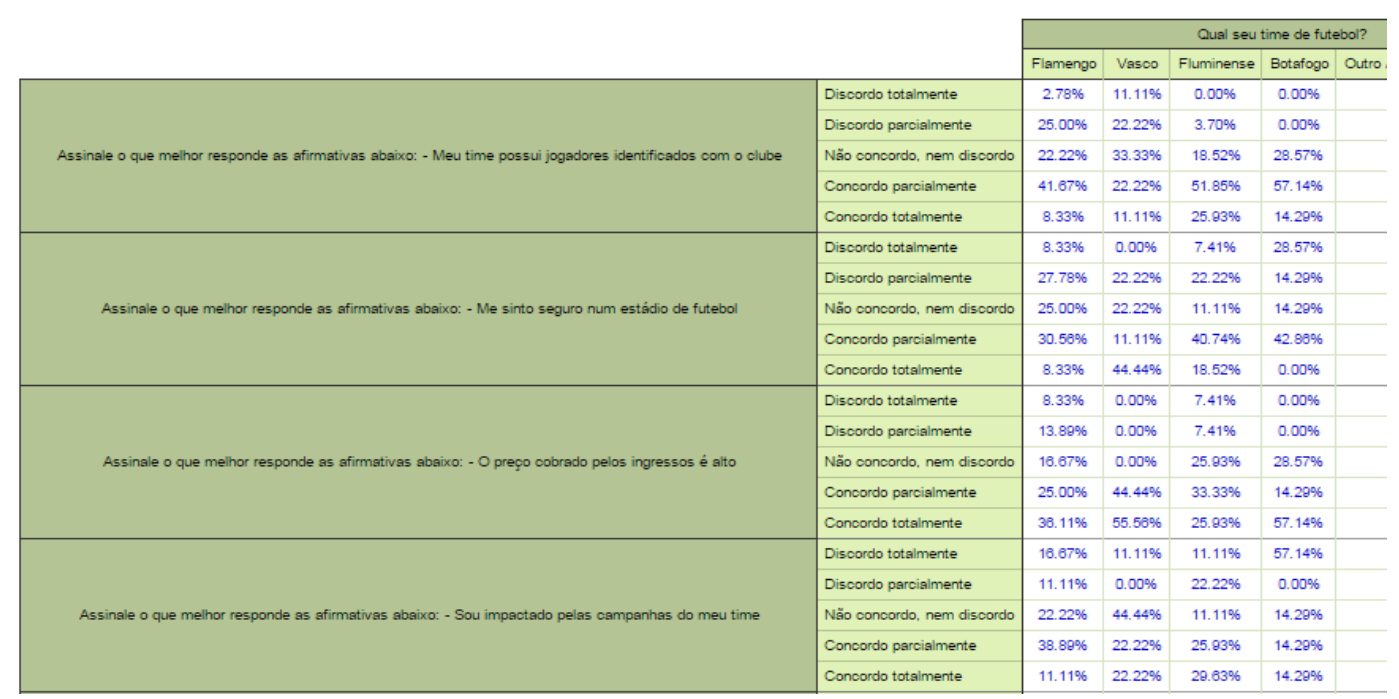


Apesar da maioria dos respondentes concordarem parcialmente (com exceção dos vascaínos), os torcedores de Fluminense e Botafogo foram os que mais se mostraram identificados com os jogadores que hoje atuam em seus clubes (indo de encontro com a estratégia adotada pelo Botafogo de sempre ter um jogador formado no clube em cada posição), enquanto que os torcedores de Flamengo e Vasco mostraram uma discordância maior (esse último com opiniões variadas).

$\mathrm{Na}$ questão da segurança, mais da metade dos torcedores de Fluminense e Vasco se sentem seguros num estádio, contra cerca de 39\% e 43\% dos torcedores de Flamengo e Botafogo, respectivamente. Vale destacar que apenas os vascaínos apresentaram um índice alto de concordância total (com 44\%).

Em se tratando da campanha para os torcedores, os torcedores do Botafogo foram os que apresentaram o pior índice de concordância, o que evidencia as ações tímidas retratada pelo gestor entrevistado. Dos demais times, os torcedores do Fluminense foram os que se mostraram ser mais impactados pelas ações do clube, com cerca de $30 \%$ dos respondentes concordando de forma total. Cerca de $45 \%$ dos torcedores de Flamengo e Vasco informaram ser impactados pelas ações de seus clubes, porém, mais da metade dos flamenguistas (39\%) se sentem impactados apenas de forma parcial.

Com base nos dados coletados entre os times Borussia Dortmund e Botafogo (onde foi possível obter informações internas) e fazendo do modelo de cinco forças de Porter, é possível verificar muitas diferenças entre a estratégia dos dois clubes:

6) Rivalidade entre os concorrentes - Enquanto o BVB é o segundo maior clube (em termos de número de torcedores) do seu país, além de ser o que mais cresce, o Botafogo segue o caminho oposto: é o clube de menor torcida em comparação aos maiores rivais de sua região e como não consegue conquistar um título expressivo há exatos 20 anos, o número de seus torcedores tem crescido numa escala muito mais lenta que os demais clubes cariocas.

(c) Barreiras à entrada de novos concorrentes - Neste quesito, BVB e Botafogo são similares por terem uma baixa ameaça de novos concorrentes, mas por motivos diferentes. No caso do BVB, esses novos concorrentes seriam os "novos ricos", que conseguem novos torcedores devido ao poder financeiro investido na formação de seus elencos, ao contrário do BVB que 
criou uma identidade forte com seus torcedores que resultaram na criação do slogan "Echte Liebe".

No caso do Botafogo, os novos concorrentes seriam clubes de menor expressão do Rio de Janeiro. Devido os clubes no Brasil não serem empresas e não poderem ser comprados (diferente da Europa), dificilmente um clube de menor expressão poderia chegar a um mesmo patamar que os clubes de maior expressão da região. Não é impossível para um clube de menor expressão ter uma alta performance, porém, dificilmente conseguirá manter seus jogadores de destaque por muito tempo, por consequência da Lei Pelé, que permite que esses jogadores sejam negociados após o pagamento de sua multa rescisória (que para um clube de maior expressão, será um valor baixo), e sem ter uma equipe de alta performance, os torcedores não teriam de torcer para esse novo time.

(6) Poder de barganha dos fornecedores - O Botafogo está vivendo uma crise financeira contraída pelas gestões anteriores e não está atualmente na elite de seu país, limitando o seu poder de barganha. $O$ valor que o clube consegue receber de patrocínios e cotas de TV acaba sofrendo uma enorme baixa.

O BVB possui um mesmo patrocinador máster há quase dez anos e os resultados da parceria elevaram a reputação do patrocinador, fazendo com que a formulação de um novo contrato contenha valores maiores dos que os formulados anteriormente, evidenciando um poder maior sobre o fornecedor.

(6) Poder de barganha dos compradores - Como as ações do Botafogo estão associadas aos resultados no futebol e o clube foi rebaixado para a $2^{a}$ divisão do campeonato nacional na temporada passada, não se pode praticar preços muito elevados no estádio, tornando o poder dos compradores alto. Não associar suas estratégias aos resultados no campo permitem que o BVB mantenha um poder baixo de barganha de seus compradores. O clube pratica preços baixos por uma questão de filosofia, não importando os resultados obtidos, tornando o poder de barganha dos compradores praticamente nulo. 
6) Ameaça de produtos substitutos - O BVB fideliza seus torcedores através dos season tickets, o que acaba impedindo que seus jogos sejam trocados por algum outro evento (neste caso, o torcedor que estará tendo prejuízo). Em se tratando do Botafogo e de clubes brasileiros de uma forma geral, essa pesquisa é motivada em verificar o que leva os torcedores a não irem aos estádios, logo, há uma alta ameaça de produtos substitutos. 


\section{Conclusões e recomendações para novos estudos}

Os resultados mostram que os torcedores brasileiros, de uma forma geral, ainda não têm uma cultura de ir ao estádio para dar suporte ao seu time no lugar de somente vê-lo ganhar. Ingressos com valores elevados que não correspondem à qualidade do espetáculo, falta de estrutura que garanta o máximo de conforto, além de uma de aproximação dos clubes com seus torcedores acabam por dificultar a ida destes ao estádio, já que parece que o torcedor precisa passar por diversos obstáculos para que se possa chegar ao evento. Essa cultura acaba sendo agravada pelo planejamento do clube estar atrelado a sua situação atual, seja pelas dívidas a pagar e principalmente a performance do time na temporada, o que acaba impedindo um melhor desenvolvimento do planejamento devido às possíveis mudanças de cenário.

Como foi visto no caso do Borussia, é necessário que exista uma reestruturação desde toda a parte interna do clube, para que aconteça um planejamento estratégico de longo prazo, com ações de marketing e relacionamento com seus torcedores bem estruturadas. Ter um estádio próprio é estrategicamente essencial, uma vez que o clube teria mais facilidade em implantar ações e alterar preços, entre outras possibilidades.

Aumentar a ocupação no estádio é um planejamento a ser feito no longo prazo, sugere-se que primeiramente os clubes brasileiros deixem de enxergar seus torcedores apenas como uma fonte de receita e siga alguns dos exemplos apresentados pelo Borussia Dortmund, que abre mão de uma boa quantia em dinheiro para manter seu torcedor satisfeito em seu estádio, mostrando sua gratidão pelo apoio recebido.

\subsection{Sugestões e recomendações para novos estudos}

Como desdobramentos futuros, essa linha de pesquisa pode ser estendida para outros times de futebol no Brasil, para se entender ainda mais a fundo a realidade que hoje vivem os principais times do país e o que pensam seus torcedores e gestores. 
Além disso, pode-se aumentar a qualidade da pesquisa com uma abordagem sobre o planejamento estratégico dos clubes através de diferentes cenários (pessimista, realista e otimista), dessa forma, os clubes não precisarão trabalhar suas estratégias de acordo com o que acontece no dia a dia do time (como percebeu-se dentro da realidade do Botafogo). 


\section{Referências Bibliográficas}

AMBROSIO TAUAN. A reconstrução do Borussia Dortmund. Goal.com. Disponível em: <http://www.goal.com/br/news/619/especiais/2013/04/30/3942356/areconstru\%C3\%A7\%C3\%A3o-do-borussia-dortmund>. Acesso em: 15 jan. 2015.

BRUNORO, J; AFIF, A. Futebol 100\% profissional. São Paulo: Gente, 1997

CARDOSO, F. Lei no 9.615, de 24 de março de 1998. Nova Lei Pelé 9.615, de 24/3/1998. Disponível em: <http://www.cbc-clubes.com.br/site/leipele/?ctd=12>. Acesso em: 5 nov. 2014.

CHIZZOTTI, Antonio. Pesquisa em ciências humanas e sociais. 2. ed. São Paulo: Cortez, 1995.

DRUCKER, Peter. A Introdução a Administração. São Paulo. Pioneira. 1984.

FUNK, D. C.; MAHONY, D. F.; HAVITZ, M. E. Sport Consumer Behavior: Assessment and

Direction. Sport Marketing Quartely, v. 12, n. 4, p. 200 -205, 2003.

GIL, Antonio. Como elaborar projetos de pesquisa. São Paulo: Atlas, 1987.

KOTLER, P. Administração de Marketing: Análise, Planejamento, Implementação e Controle. $2^{\underline{a}}$ ed. São Paulo: Atlas, 1992.

MAXIMIANO, Antonio Cesar Amaru. Introdução à Administração. 6. ed. São Paulo: Atlas, 2006.

MORGAN, M.; SUMMERS, J. Marketing Esportivo. São Paulo: Thomson Learning,2008.

REIN, I.; KOTLER, P.; SHIELDS, B. Marketing Esportivo: a reinvenção do esporte na busca de torcedores. Porto Alegre: Bookman, 2008.

GLOBO ESPORTE. Da falência à final europeia: o "Amor verdadeiro" que move o Borussia. Globoesporte.com, Rio de Janeiro, 23 mai 2013. Disponível em: < http://globoesporte.globo.com/futebol/liga-doscampeoes/noticia/2013/05/da-falencia-final-europeia-o-amor-verdadeiro-quemove-o-borussia.html >. Acesso em: 18 mar. 2015.

WASSERMANN, R. O Brasil é o país do futebol? BBC Brasil, 12 jun. 2013. Disponível em: http://www.bbc.co.uk/portuguese/noticias/2013/06/130611_brasil_pais_do_futebo I_rw.shtml >. Acesso em: 14 out. de 2014.

ADMINISTRADORES.COM. Administradores.com. Administradores - O Portal 
da Administração, 2003. Disponível em: <http://www.administradores.com.br/>. Acesso em: 13 nov. 2014

PLURI CONSULTORIA. Pluri Consultoria. Pluri Consultoria, 2011. Disponível em: <http://www.pluriconsultoria.com.br/>. Acesso em: 11 out. 2014

DAILY MAIL. Daily Mail. Daily Mail, 1997. Disponível em: <http://www.dailymail.co.uk/home/index.html>. Acesso em: 21 nov. 2014

SINOPSE DO FUTEBOL. Sinopse do futebol alemão. Sinopse do Futebol, 19 abr. 2012 . Disponível em: < http://sinopsedofutebol.blogspot.com.br/2012/04/maiores-da-alemanha.html>. Acesso em: 14 out. de 2014.

GLOBO ESPORTE. A base: Lei Pelé, empresários, talentos fatiados e sonho com futebol europeu. Globoesporte.com, Rio de Janeiro, 26 out. 2014. Disponível em: <http://globoesporte.globo.com/programas/esporteespetacular/noticia/2014/10/base-lei-pele-empresarios-talentos-fatiados-e-sonhocom-futebol-europeu.html>. Acesso em: 13 abr. 2015.

RESENDE, I. Barato, bom e lotado: Borussia Dortmund, o maior sucesso de público da Europa. Blog BVB Brasil, 04 mar. 2013. Disponível em: <http://brasilbvb.blogspot.pt/2013/03/barato-bom-e-lotado-borussia-dortmund-o.html>.

Acesso em: 26 nov. 2014

ARAUJO, C. F. S. Sacodindo a poeira. Blog Um Facho de Luz, Globoesporte.com, 07 jun. 2013. Disponível em: <http://globoesporte.globo.com/rj/torcedor-botafogo/platb/tag/borussiadortmund/l>. Acesso em: $06 \mathrm{dez} .2014$.

ARMÁRIO DA BOLA. Especial Borussia Dortmund 2013. Blog Armário da Bola, 06 set. 2013.2 Disponível em: <https://armariodabola.wordpress.com/2013/09/06/borussia-dortmund-2013/>. Acesso em: 11 fev. 2015.

PANEQUE, W. Carsten Cramer: o marqueteiro por trás do 'Exchte Lierbe'. Uol, 09 set. 2014. Disponível em: <http://espnfc.espn.uol.com.br/borussiadortmund/muralha-amarela/carsten-cramer-o-marketeiro-por-tras-do-echteliebe>. Acesso em: 12 fev. 2015.

SUZUKI, F. Pelé, agora, critica a lei que batizou. Lancenet, Equipe De Prima, 24 mai. 2014.2 Disponível em: <http://blogs.lancenet.com.br/deprima/2014/04/24/pele-agora-critica-a-lei-quebatizou/>. Acesso em: 13 abr. 2015.

COIMBRA, D. Vexame dos 7 a 1 no Mineirão começou com a Lei Pelé. Blog do David Coimbra, 9 jul. 2014. Disponível em: < http://wp.clicrbs.com.br/davidcoimbra/2014/07/09/vexame-dos-7-a-1-no-mineiraocomecou-com-a-lei-pele/?topo=13,1,1,,,13>. Acesso em: 14 abr. 2015.

SINEDINO, E. Vinte perguntas: Lei Pelé. Nominuto.com, 8 jun. 2008. Disponível em: <http://www.nominuto.com/noticias/esporte/vinte-perguntas-leipele/16997/>. Acesso em: 14 abr. 2015. 
LOBO, F. Dortmund mostra que é possível clubes fazerem algo contra torcedores mal comportados. Trivela.uol.com.br, 26 fev 2014. Disponível em: < http://trivela.uol.com.br/dortmund-mostra-que-e-possivel-clubes-fazerem-algocontra-torcedores-mal-comportados/

>. Acesso em: 09 abr. 2015.

DE ESCUDEIRO, L. "Sem cerveja para racistas" é a nova campanha do Dortmund contra a discriminação. Trivela.uol.com.br, 11 mar 2015. Disponível em: < http://trivela.uol.com.br/sem-cerveja-para-racistas-e-a-nova-campanha-dodortmund-contra-a-discriminacao/

>. Acesso em: 09 abr. 2015.

STEIN, L. Planejamento: mais um ótimo exemplo dado pelo Dortmund. Trivela.uol.com.br, 08 jul 2013. Disponível em: < http://trivela.uol.com.br/planejamento-na-montagem-do-elenco-mais-um-bomexemplo-do-dortmund/ >. Acesso em: 09 abr. 2015.

STEIN, L. Bayern tem maior torcida, mas Dortmund é o que mais cresce. Trivela.uol.com.br, 22 mai 2013. Disponível em: < http://trivela.uol.com.br/obayern-e-o-mais-popular-mas-dortmund-e-o-que-mais-cresce/ >. Acesso em: 09 abr. 2015.

STEIN, L. Para limpar um pouco da barra, jogadores serviram chopes à torcida do Dortmund. Trivela.uol.com.br, 03 dez 2014. Disponível em: < http://trivela.uol.com.br/para-limpar-um-pouco-da-barra-jogadores-dortmundforam-servir-chopes-torcida/ >. Acesso em: 09 abr. 2015.

BONSANTI, B. Fidelidade: Dortmund ganhou mais sócios que a média na semana em que foi lanterna. Trivela.uol.com.br, 10 mar 2015. Disponível em: < http://trivela.uol.com.br/fidelidade-dortmund-ganhou-mais-socios-que-a-mediana-semana-em-que-foi-lanterna/ >. Acesso em: 09 abr. 2015.

CORREA, K. Conceito de planejamento estratégico. Administração e Gestão, 03 jun 2008. Disponível em: < http://www.administracaoegestao.com.br/planejamento-estrategico/conceito-deplanejamento-estrategico/ >. Acesso em: 12 fev. 2015.

SEM AUTOR. O que é planejamento e gestão estratégica? Portal Administração, 2014. Disponível em: < http://www.portaladministracao.com/2014/06/planejamento-gestao-estrategica-o-que-e.html I > . Acesso em: 12 fev. 2015.

MARTINS, R. Borussia Dortmund, o sinônimo de uma parceria de sucesso. Lancenet, 03 out. 2012. Disponível em: <http://www.lancenet.com.br/minuto/Borussia-Dortmund-sinonimo-parceriasucesso_0_785321475.html>. Acesso em: 16 mai. 2015.

SEM AUTOR. ANÁLISE DE COMPETITIVIDADE: AS CINCO FORÇAS DE PORTER, M. Smart Consultoria Jr, 30 abr 2014. Disponível em: < http://smartconsultoria.com/analise-de-competitividade-as-cinco-forcas-deporter/>. Acesso em: 13 fev. 2015.

SEM AUTOR. As cinco forças de Porter. Blog Executivo Inteligente, 19 mai 2010. Disponível em: < https://sites.google.com/site/executivointeligente/as- 
cinco-forcas-de-porter>. Acesso em: 13 fev. 2015.

MARQUES JUNIOR, F. L. A parceria entre o Borussia Dortmund e Evonik: Aula de marketing esportivo! Copcom - Comunicação e Marketing, 28 jul 2014. Disponível em: < https://comunicopcom.wordpress.com/2014/07/28/aparceria-entre-o-borussia-dortmund-e-evonik-aula-de-marketing-esportivo/>. Acesso em: 16 mai. 2015.

BECKER, G. Goleada alemã também nas arquibancadas. Deutsche Welle, 04 mai 2015. Disponível em: < http://www.dw.de/goleada-alem\%C3\%A3tamb\%C3\%A9m-nas-arquibancadas/a-18426750>. Acesso em: 16 mai. 2015.

DANTE DA SILVEIRA, M. C. Estudo de caso: breve análise e adequação à pesquisa jurídica. DireitoNet, 26 jun 2005. Disponível em: < http://www.direitonet.com.br/artigos/exibir/2105/Estudo-de-caso-breve-analise-eadequacao-a-pesquisa-juridica >. Acesso em: 21 fev. 2015.

SEM AUTOR. Site oficial do Borussia Dortmund. Borussia Dortmund GmbH \& Co. KGaA, 1996. Disponível em: < http://www.bvb.de/eng >. Acesso em: 11 out. 2014.

SEM AUTOR. Site oficial da FIFA. Borussia Dortmund, 1994. Disponível em: < http://www.fifa.com/ >. Acesso em: 13 abr. 2015. 


\section{Anexo 1}

\section{Roteiro de pesquisa com gestores de futebol}

- O clube possui um planejamento estratégico? Como as estratégias são estruturadas?

- Quais os principais problemas e ameaças do clube? E os pontos fortes e oportunidades?

- Quais as principais fontes de renda do clube?

- Como o clube obtém recursos necessários para funcionar (receita, jogadores, estádio, etc)? Como se dá a relação com esses fornecedores?

- Como é feito o planejamento da montagem do elenco? Procura-se criar uma identidade com os torcedores?

- Você acha que a presença dos torcedores nos estádios é relevante? Como o clube estimula o seu torcedor?

- Como o clube trabalha para tornar a ida dos torcedores ao estádio em uma experiência agradável (segurança, acesso, preço do evento)? 


\title{
Anexo 2
}

\section{Roteiro de pesquisa com torcedores}

\author{
Q1 Qual seu gênero? \\ O Masculino \\ O Feminino
}

Q2 Indique sua idade:
O Abaixo de 18 anos
O Entre 18 e 28 anos
O Entre 29 e 39 anos
O Entre 40 e 50 anos
O Entre 51 e 61 anos
O Acima de 62 anos

Q3 Qual seu time de futebol?
O Flamengo
O Vasco
O Fluminense
Botafogo
O Outro / Não gosto de futebol

Q4 Quantas vezes por ano você costuma ir ao estádio?
O Nenhuma
O 1 a 3 vezes
O 4 a 6 vezes
O 7 a 9 vezes
O 10 vezes ou mais

Q5 Numere o grau de importância (sendo 1 o maior e 6, o menor) dentre os itens abaixo caso você pense em ir a um estádio de futebol:

Situação do time no campeonato

Presença de ídolo(s) no time

Segurança

Preço dos ingressos

Campanha para os torcedores

Acesso (Transporte) 
Q6 Assinale o que melhor responde as afirmativas abaixo:

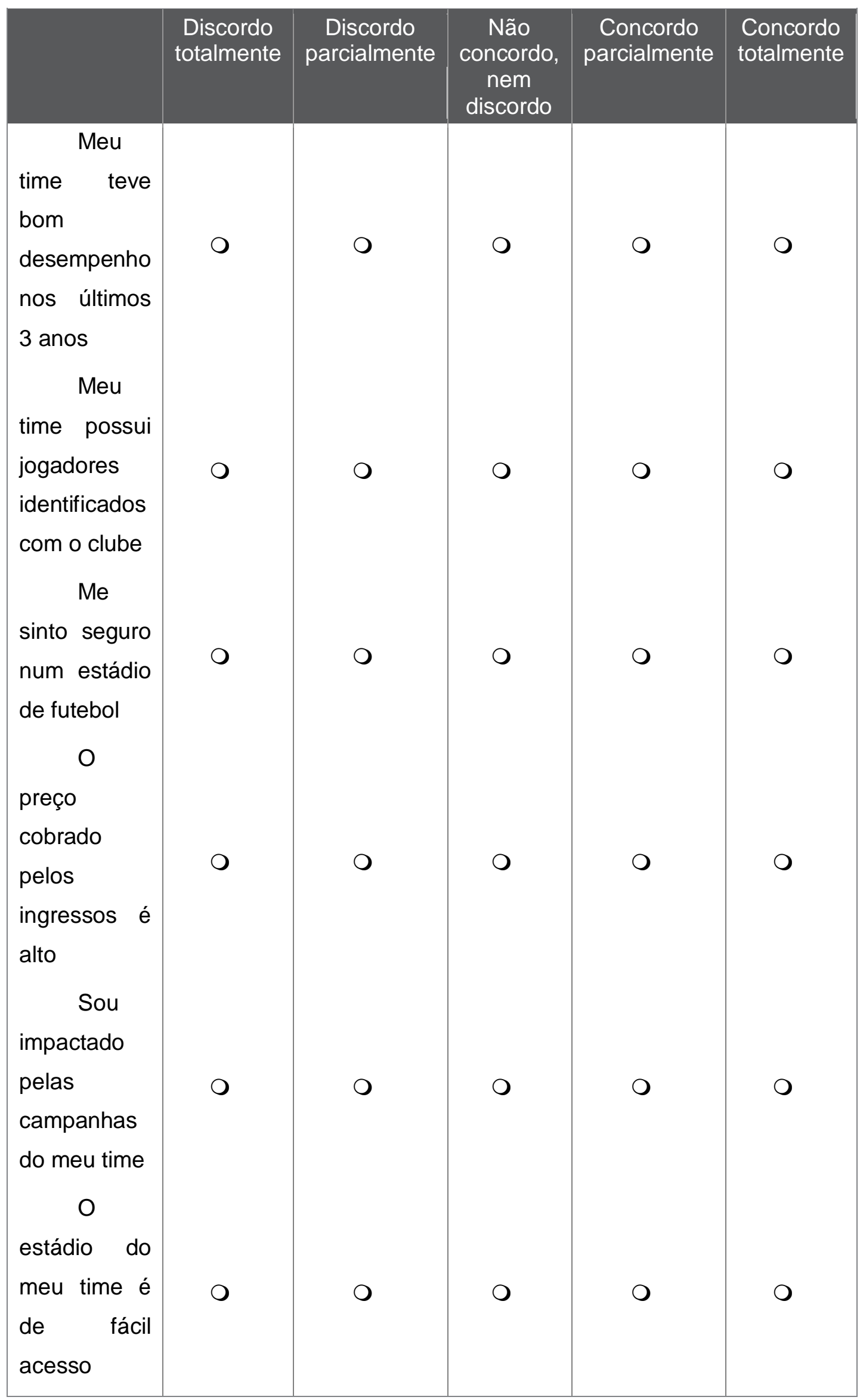


Q7 Você é sócio torcedor do seu time?

O Sim

O Não

Q8 Em relação ao seu time, indique abaixo o perfil de torcedor mais adequado com o seu:

F Fanático [Totalmente identificado com o time, raramente faltando um evento esportivo]

Conhecedor [Fã que tem amplo acesso e intensa participação nos eventos esportivos]

Agregado [Torcedor que quer estar sempre junto do seu time e ídolos e ter oportunidades de interação]

O Colecionadores [Fã sempre disposto a pagar por produtos que simbolizem o seu time]

O Gastador [Disposto a investir uma grande quantia pelo prazer do esporte]

O Curioso [Costuma se relacionar com o time por meio de mídias, raramente comparecendo aos eventos esportivos]

O Indiferente [Pessoa que não tem interesse pelo esporte] 